\title{
Endocrinologic Control of Men's Sexual Desire and Arousal/Erection
}

\author{
Giovanni Corona, MD, $\mathrm{PhD}^{1}$ Andrea M. Isidori, MD, $\mathrm{PhD}_{1}^{2}$ Antonio Aversa, MD, $\mathrm{PhD}{ }^{2,3}$ \\ Arthur L. Burnett, MD, $\mathrm{PhD}^{4}$ and Mario Maggi, MD, $\mathrm{PhD}^{5}$
}

\begin{abstract}
Introduction: Several hormones and neurotransmitters orchestrate men's sexual response, including the appetitive (sexual desire) and consummative (arousal and penile erection) phases.

Aim: To provide an overview and recommendations regarding endocrinologic control of sexual desire and arousal and erection and their disturbances.

Methods: Medical literature was reviewed by the subcommittee of the International Consultation of Sexual Medicine, followed by extensive internal discussion, and then public presentation and discussion with other experts. The role of pituitary (prolactin, oxytocin, growth hormone, and $\alpha$-melanocyte-stimulating hormone), thyroid, and testicular hormones was scrutinized and discussed.
\end{abstract}

Main Outcome Measures: Recommendations were based on grading of evidence-based medical literature, followed by interactive discussion.

Results: Testosterone has a primary role in controlling and synchronizing male sexual desire and arousal, acting at multiple levels. Accordingly, meta-analysis indicates that testosterone therapy for hypogonadal individuals can improve low desire and erectile dysfunction. Hyperprolactinemia is associated with low desire that can be successfully corrected by appropriate treatments. Oxytocin and $\alpha$-melanocyte-stimulating hormone are important in eliciting sexual arousal; however, use of these peptides, or their analogs, for stimulating sexual arousal is still under investigation. Evaluation and treatment of other endocrine disorders are suggested only in selected cases.

Conclusion: Endocrine abnormalities are common in patients with sexual dysfunction. Their identification and treatment is strongly encouraged in disturbances of sexual desire and arousal.

J Sex Med 2016;13:317-337. Copyright (C) 2016, International Society for Sexual Medicine. Published by Elsevier Inc. All rights reserved.

Key Words: Sexual Desire; Erectile Dysfunction; Testosterone

\section{INTRODUCTION}

Cells communicate with one another through a discrete flow of molecules that consistently influence their behavior and activity. Two distinct classes of communicating molecules are recognized

Received September 29, 2015. Accepted January 15, 2016.

'Endocrinology Unit, Medical Department, Azienda USL Bologna, MaggioreBellaria Hospital, Bologna, Italy;

${ }^{2}$ Department of Experimental Medicine, Sapienza University of Rome, Rome, Italy;

${ }^{3}$ Deptartment of Experimental and Clinical Medicine, University Magna Graecia, Catanzaro, Italy;

${ }^{4}$ Department of Urology, the James Buchanan Brady Urological Institute, The Johns Hopkins University School of Medicine, Baltimore, MD, USA;

${ }^{5}$ Sexual Medicine and Andrology Unit, Department of Biomedical, Clinical and Experimental Sciences, University of Florence, Florence, Italy

Copyright ( $)$ 2016, International Society for Sexual Medicine. Published by Elsevier Inc. All rights reserved.

http://dx.doi.org/10.1016/j.jsxm.2016.01.007 and classified according to their origin and fate: neurotransmitters and hormones. Hormones often are derived from endocrine glands and reach their target cells through the bloodstream, whereas neurotransmitters are locally generated and bioactive within the synaptic cleft. However, some communicating molecules often act as a neurotransmitter or as a hormone (eg, noradrenaline, OT, and $\alpha-\mathrm{MSH})$. Any interference with endocrine cell-to-cell communication because of over- (hyper-) or under- (hypo-) flow results in pathologic conditions. Because communication is very important in the dyadic field of sexual medicine, it obvious that endocrine disorders can greatly affect the sexual brain (desire) and the sexual body (arousal and erection).

This article presents a summary of the main endocrine control of men's sexual desire and arousal and erection as discussed by the authors at their presentation at the Fourth International Consultation of Sexual Medicine (Madrid, Spain, June 2015). After the past three International Consultations on Sexual Medicine, significant advances in the understanding of the endocrinology of male sexual function 


\section{RECOMMENDATIONS}

\section{Recommendation 1}

- Testosterone $(\mathrm{T})$ significantly contributes to the regulation of male sexual desire (level $1 \mathrm{~A})$, and $\mathrm{T}$ treatment (TTh) can improve libido in hypogonadal (total $\mathrm{T}<12 \mathrm{nmol} / \mathrm{L}$ ) men (level $1 \mathrm{~A}$ ).

- $\mathrm{T}$ evaluation is strongly recommended in all men complaining of decreased sexual desire (level 1A).

\section{Recommendation 2}

- Dihydrotestosterone (DHT) and estrogens play a minor role in the regulation of male sexual desire (level 2B).

- DHT and estradiol (E2) evaluations are not recommended in men complaining of decreased sexual desire (level 3B).

\section{Recommendation 3}

- Adrenal hormones, including dehydroepiandrosterone (DHEA) and its sulfate (DHEAS; level 2A), and cortisol and aldosterone (level 3B) are not involved in the regulation of male sexual desire.

- Adrenal hormone evaluation is not recommended in men complaining of decreased sexual desire (level $1 \mathrm{~A})$.

\section{Recommendation 4}

- Prolactin (PRL) plays a major role in regulating male sexual desire (level 2A), acting through direct and indirect pathways (level 3B).

- PRL levels should be evaluated in all men complaining of decreased sexual desire (level 2A).

- Treating hyperprolactinemia restores sexual desire (level $2 \mathrm{~A}$ ).

\section{Recommendation 5}

- The contribution of thyroid hormones (THs) in the regulation of male sexual desire is contradictory (level 3B).

- TH evaluation is not recommended in men complaining of decreased sexual desire (level 2B).

\section{Recommendation 6}

- T regulates penile development and growth in early life, but not after puberty (level A).

- T targets several molecular pathways involved in the physiology of erections, including the nitric oxide and cyclic guanosine monophosphate (NO-cGMP) pathway (level A), RhoA-ROCK signaling, adrenergic response, and cavernous smooth muscle cell (SMC) turnover (level B).

\section{Recommendation 7}

- The decrease of circulating $\mathrm{T}$ levels is associated with a decrease in erectile function (EF; level 2B).

- TTh in hypogonadal men (total T level $<12 \mathrm{nmol} / \mathrm{L}$ ) is associated with significant increases in self-reported measurements of EF that are proportional to the severity of hypogonadal status before treatment (level 1A).

- Basal and longitudinal assessments of $\mathrm{T}$ are recommended in men with erectile dysfunction (ED; level $1 \mathrm{~A}$ ).

\section{Recommendation 8}

- DHT exerts qualitatively similar effects as T on EF (level 2A), although it has been studied less extensively.

- Treatment with DHT and its analogs (mesterolone) cannot be recommended as an alternative to TTh to improve EF in hypogonadal men (level 4B).

- Measurement of DHT is not recommended in the assessment of EF (level 3A).

\section{Recommendation 9}

- The role of E2 on EF is controversial. Experimental evidence indicates that E2 downregulates phosphodiesterase type 5 (PDE5) expression (level 3C).

- Measurement of estrogens is not recommended in the assessment of EF (level 2C).

\section{Recommendation 10}

- DHEA and DHEAS are not involved in the regulation of male EF (level 2A).

- Glucocorticoid and mineralocorticoid in adrenal insufficiency might play a role in restoring EF (level 4C).

\section{Recommendation 11}

- PRL does not play a direct role in the regulation of male EF (level 3B).

- PRL evaluation is not recommended in patients complaining of ED (level 2B).

- Treating hyperprolactinemia might have indirect, positive effects on arousal and erection (level 3B) 


\section{Recommendation 12}

- Conclusive data regarding the potential therapeutic role of oxytocin (OT) in male sexual dysfunctions are lacking (level 2B).

\section{Recommendation 13}

- Growth hormone (GH) and insulin-like growth factor-1 (IGF-1) are not involved in the regulation of male EF (level 3B).

- GH and IGF-1 levels should not be evaluated in men complaining of ED (level 2B).

\section{Recommendation 14}

- Animal models indicate that the melanocortin system is involved in the regulation of EF acting at a central level (level 2C).

- Available randomized controlled trials (RCTs) do not suggest analogs of $\alpha$-melanocyte-stimulating hormone ( $\alpha$-MSH) for the treatment of ED because of associated adverse events (level 1B).

\section{Recommendation 15}

- Hyperthyroidism is significantly associated with an increased risk of ED (level 3B).

- Treating hyperthyroidism improves ED (level 3B).

- Sexual function should be assessed in all men with hyperthyroidism (level 3B).

- The prevalence of hyperthyroidism in men seeking medical care for ED is low (level 2B).

- TH evaluation is not recommended in all men complaining of ED (level 2B).

- The association between hypothyroidism and impairment of EF is contradictory (level 2C).

- Sexual function should not be assessed in all men with hypothyroidism (level 2B).

- The prevalence of hypothyroidism in men seeking medical care for ED is low (level 2B).

- TH evaluation is not recommended in all men complaining of ED (level 2B).

have been obtained. This report aims to provide recommendations focusing on the pathophysiology of male sexual dysfunctions, specifically on the endocrine aspects. In particular, the aim of this article was to scrutinize studies analyzing the effect of hormone alterations, and their treatments, on sexual desire and arousal and erection.

\section{HORMONES AND SEXUAL DESIRE}

\section{Sex steroids (T, DHT, and E2)}

There is much evidence documenting $\mathrm{T}$ as the fuel of male sexual desire. ${ }^{1-7}$ However, the contribution of $\mathrm{T}$ in the agerelated decline of male sexual desire is contradictory, at least in the general population. The Olmsted Longitudinal Study, ${ }^{5}$ a stratified random sample of 414 men, failed to find any association between total $\mathrm{T}$ and sexual desire after adjusting for age. The Massachusetts Male Aging Study (MMAS) ${ }^{6}$ found only a modest difference in mean $\mathrm{T}$ levels between subjects with and without low libido $(0.12 \mathrm{nmol} / \mathrm{L})$. In contrast to these reports, the European Male Aging Study (EMAS), a population-based survey performed on more than 3,400 men recruited from eight European centers, ${ }^{7}$ clearly showed that a decreased frequency of sexual thoughts is one of the more specific symptoms associated with $T$ deficiency. However, it is important to emphasize that the same study showed that the simultaneous presence of three sexual symptoms (low sexual desire, decreased morning erections, and ED) was the strongest predictor of low $\mathrm{T}$, suggesting that sexual symptoms, in this combination, are the most sensitive and specific in identifying patients with low T levels. ${ }^{7}$ Similar results were reported more recently by the Testosterone Trials (TTrials), ${ }^{8}$ a survey performed in 788 community-dwelling men recruited from 12 sites in the United States. In addition, the Concord Health and Aging in Men Projects (CHAMP), ${ }^{9}$ a prospective population-based observational study enrolling 1,226 men older than 70 years and followed for 2 years, found a consistent association between the decrease of $\mathrm{T}$ and the decrease of sexual desire. In particular,

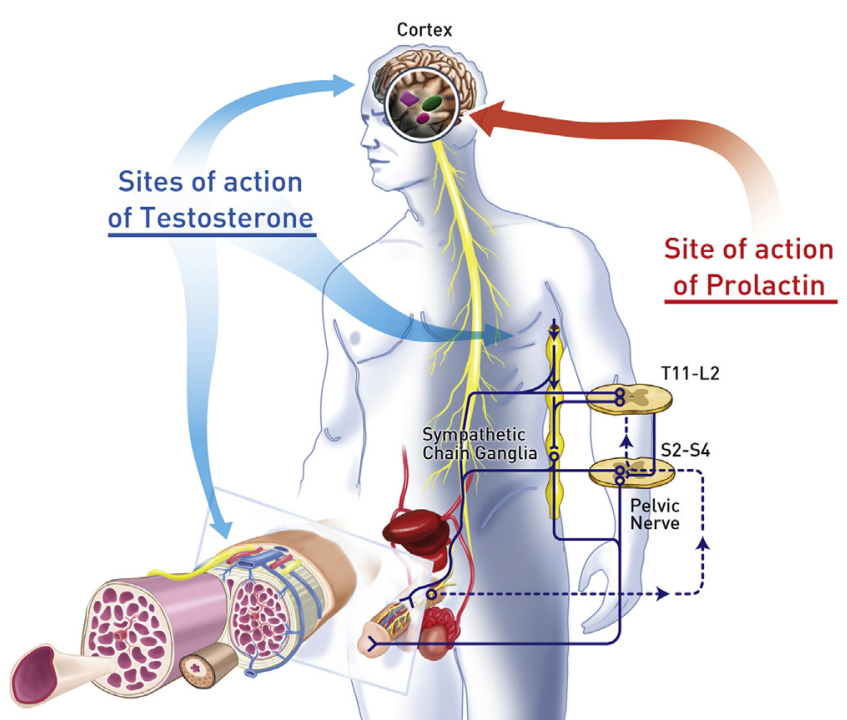

Figure 1. Sites of action of testosterone and prolactin in regulating male sexual desire and arousal and erection. Adapted from Isidori et al. ${ }^{75}$ Figure 1 is available in color online at www.jsm.jsexmed.org. 
Table 1. Characteristics and Outcomes of Randomized, Placebo-Controlled Clinical Studies Included in Meta-Analysis*

\begin{tabular}{|c|c|c|c|c|c|c|c|c|c|}
\hline Study & $\begin{array}{l}\text { Patients } \\
\text { (T/placebo), } n\end{array}$ & $\begin{array}{l}\text { Trial } \\
\text { duration } \\
\text { (wk) }\end{array}$ & Age (y) & $\mathrm{T}$ levels & Dose (daily) & Design & $\begin{array}{l}\text { Sexual function } \\
\text { tool used }\end{array}$ & EF domain & Libido domain \\
\hline \multicolumn{10}{|l|}{ Eugonadal } \\
\hline $\begin{array}{l}\text { O'Carroll and } \\
\text { Bancroft, } \\
1984\end{array}$ & $20 / 20$ & 12 & 19-64 & Eugonadal & $\begin{array}{l}\text { Sustanon } 250 \mathrm{mg} / \\
2 \mathrm{wk}\end{array}$ & Crossover & $\begin{array}{l}\text { Specific questions } \\
\text { on sexual } \\
\text { function }\end{array}$ & $\begin{array}{c}-0.13(-1.73 \text { to } 1.48) \\
P=.88+; 0.34 \\
(-0.59 \text { to } 1.27) \\
P=.48 \neq\end{array}$ & $\begin{array}{l}0.79(-0.23 \text { to } 1.81) \\
P=.13+; 0.09 \\
(-0.83 \text { tol.02), } \\
P=.84 \ddagger\end{array}$ \\
\hline $\begin{array}{l}\text { Anderson et al, } \\
1992\end{array}$ & $16 / 15$ & 4 & $21-41$ & Eugonadal & TE 200 mg/wk & parallel & SES score & $\begin{array}{c}-0.20(-0.91 \text { to } \\
0.51), P=.58\end{array}$ & $\begin{array}{l}0.08(-0.62 \text { to } \\
0.78), P=.82\end{array}$ \\
\hline $\begin{array}{l}\text { Aydin et al, } \\
1996\end{array}$ & 20/18 & 8 & 36.8 & Eugonadal & TU 160 mg/d & Parallel & $\begin{array}{l}\text { Specific questions } \\
\text { on sexual } \\
\text { function }\end{array}$ & $\begin{array}{l}0.16(-0.57 \text { to } 0.89) \\
P=.67\end{array}$ & - \\
\hline $\begin{array}{l}\text { Svartberg et al, } \\
2004\end{array}$ & $15 / 14$ & 26 & $54-75$ & Eugonadal & TE 250 mg/mo & Parallel & IIEF-5 & $\begin{array}{l}0.90(0.06-1.74) \\
P=.04\end{array}$ & - \\
\hline Overall eugonadal & & & & & & & & $\begin{array}{l}0.22(-0.17 \text { to } 0.61) \\
P=.26\end{array}$ & $\begin{array}{c}0.25(-0.24 \text { to } 0.74) \\
P=.32\end{array}$ \\
\hline \multicolumn{10}{|l|}{ Mixed } \\
\hline $\begin{array}{l}\text { Benkert et al, } \\
1979\end{array}$ & 13/16 & 8 & $45-75$ & Eugonadal & TU 120 mg/d & Parallel & CGI scale & $\begin{array}{r}-0.26(-1.08 \text { to } \\
0.56), P=.54\end{array}$ & - \\
\hline $\begin{array}{l}\text { Gluud et al, } \\
1988\end{array}$ & $64 / 46$ & 30 & $24-79$ & Mixed & TU 400 mg/d & Parallel & $\begin{array}{l}\text { Specific questions } \\
\text { on sexual } \\
\text { function }\end{array}$ & $\begin{array}{c}0.27 \text { (-0.11 to } 0.65) \\
P=.17\end{array}$ & $\begin{array}{c}0.20(-0.18 \text { to } 0.58) \\
P=.31\end{array}$ \\
\hline $\begin{array}{l}\text { Schiavi et al, } \\
1997\end{array}$ & $7 / 5$ & 6 & $46-67$ & Mixed & TE 200 mg/2 wk & Crossover & BSF score & $\begin{array}{c}0.00 \text { (-1.15 to } 1.15) \\
P=1.00\end{array}$ & $\begin{array}{l}2.40(0.90-3.90), P \\
\quad<.0001\end{array}$ \\
\hline $\begin{array}{l}\text { Rabkin et } \mathrm{al}_{,}^{17} \\
2000\end{array}$ & $39 / 35$ & 6 & $67.7 \pm 3.8$ & Mixed & TC $200 \mathrm{mg} / 2 \mathrm{wk}$ & Parallel & CGI scale & - & $\begin{array}{l}0.76(0.27-1.24), P \\
\quad<.0001\end{array}$ \\
\hline $\begin{array}{l}\text { Haren et al, } \\
2005\end{array}$ & $39 / 37$ & 48 & $68.5 \pm 6.0$ & Mixed & TU $160 \mathrm{mg} / \mathrm{d}$ & Parallel & $\begin{array}{l}\text { ADAM } \\
\text { questionnaire }\end{array}$ & $\begin{array}{l}0.28 \text { ( }-0.55 \text { to } 1.11) \\
P=.51\end{array}$ & $\begin{array}{l}0.50(0.04-0.95) \\
P=.03\end{array}$ \\
\hline Overall mixed & & & & & & & & $\begin{array}{l}0.18(-0.13 \text { to } 0.48) \\
P=.26\end{array}$ & $\begin{array}{c}0.64(0.14-1.13) \\
P=.01\end{array}$ \\
\hline \multicolumn{10}{|l|}{ Hypogonadal } \\
\hline $\begin{array}{l}\text { Nankin et al, } \\
1986\end{array}$ & $10 / 10$ & 12 & $51-72$ & $<12 \mathrm{nmol} / \mathrm{L}$ & TC $200 \mathrm{mg} / 2 \mathrm{wk}$ & Crossover & $\begin{array}{l}\text { Specific questions } \\
\text { on sexual } \\
\text { function }\end{array}$ & - & $\begin{array}{l}0.50(-0.39 \text { to } 1.39) \\
P=.27\end{array}$ \\
\hline $\begin{array}{l}\text { Dobs et al, } \\
1998\end{array}$ & $7 / 6$ & 8 & $41 \pm 16$ & $<8 \mathrm{nmol} / \mathrm{L}$ & $\begin{array}{l}\text { Buccal T 10-20 } \\
\text { mg/d }\end{array}$ & Parallel & WSF score & - & $\begin{array}{l}0.67(-0.45 \text { to } 1.79), \\
P=.24\end{array}$ \\
\hline
\end{tabular}




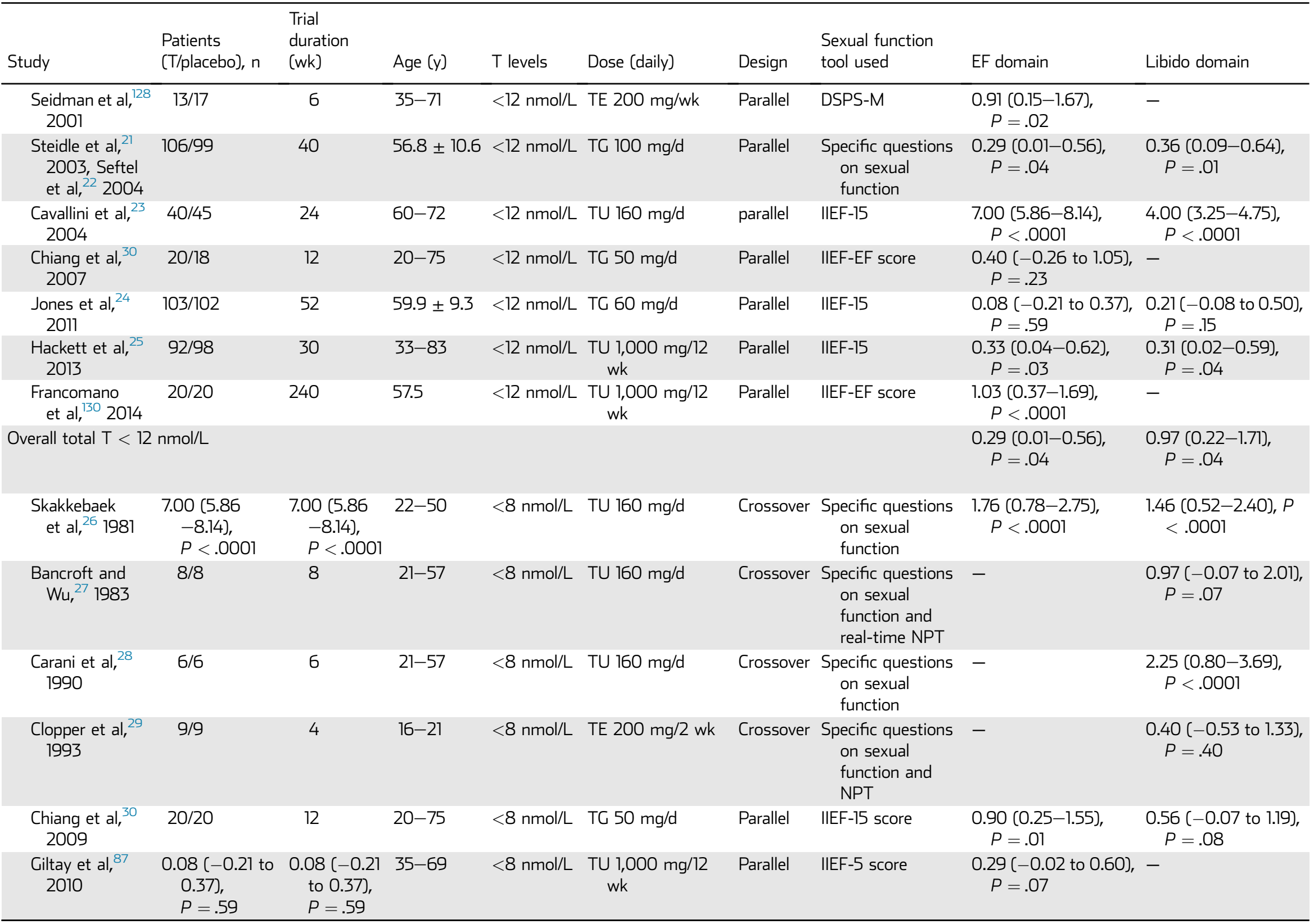


men whose sexual desire decreased during the 2-year follow-up period showed a nearly $10 \%$ decrease in circulating $\mathrm{T}$ levels. Incidence of secondary hypogonadism in a 4.3-year follow-up observational EMAS cohort was associated with new or worsening of low libido, ED, and infrequent spontaneous erections. ${ }^{10}$ All these epidemiologic studies support the genuine association between androgens and sexual desire in humans.

The presence of androgen receptors in distinct areas of the human brain have been described as involved in the regulation of the male sexual response. Among these, the most important include the temporal, preoptic, hypothalamus, amygdala, midbrain, frontal, and prefrontal areas and cingulate gyrus (Brodmann area 24) ${ }^{11}$ (Figure 1).

Corona et $\mathrm{al}^{4}$ recently performed the largest meta-analysis published thus far scrutinizing the role of TTh on several aspects of male sexual function. Data on the effect of TTh on the libido component were available in 17 studies that together enrolled 1,111 individuals $^{12-30}$ (Table 1). Overall, TTh was found to improve libido, but this was not confirmed in those studies considering only eugonadal patients at enrollment ( $T$ levels $<12 \mathrm{nmol} / \mathrm{L}$ ), without any differences in studies enrolling subjects with milder ( $\mathrm{T}$ levels $<12 \mathrm{nmol} / \mathrm{L}$ ) or more severe ( $\mathrm{T}$ levels $<8 \mathrm{nmol} / \mathrm{L}$ ) forms of hypogonadism (Table 1). Metaregression analysis of the entire sample showed a trend toward an inverse relation between baseline mean $T$ levels and the effect size on the libido component, which reached statistical significance when studies enrolling eugonadal or mixed eugonadal and hypogonadal subjects at baseline were excluded from the analysis. ${ }^{4}$ Decreasing $\mathrm{T}$ using gonadotropin-releasing hormone analogs, as in healthy men for contraception purposes ${ }^{31}$ or in patients with advanced prostate cancer, ${ }^{32,33}$ produced a negative effect on libido.

\section{RECOMMENDATION 1}

- $T$ significantly contributes to the regulation of male sexual desire (level 1A), and TTh can improve libido in hypogonadal (total T level $<12 \mathrm{nmol} / \mathrm{L}$ ) men (level $1 \mathrm{~A})$.

- $\mathrm{T}$ evaluation is strongly recommended in all men complaining of decreased sexual desire (level 1A).

The role played by DHT in the control of male sexual desire is contradictory. In fact, patients with congenital $5 \alpha$-reductase (5AR) type 2 deficiency (a rare genetic disorder characterized by a decreased conversion of T into DHT) after puberty often have normal sexual desire. ${ }^{34}$ In line with this evidence, the CHAMP study did not report any association between mass-derived DHT and sexual desire. ${ }^{9}$ However, recent evidence documented a decrease of sexual desire in patients taking $5 \mathrm{AR}$ inhibitors (5ARis), which cause a decrease in DHT circulating levels, suggesting a direct role in the regulation of male sexual desire. ${ }^{35}$ Interestingly, in some cases, the decrease of sexual desire persisted even after 5ARi was withdrawn. ${ }^{35}$ A possible explanation is that blocking $5 \mathrm{AR}$ in the brain could impair other $5 \mathrm{AR}$ 
steroid metabolites that act as neurosteroids ${ }^{35}$ to regulate sexual desire. In line with these data, there is significant corroborative evidence that administration of non-aromatization androgens such as DHT, nandrolone, or mesterolone can improve male sexual function. Oral DHT undecanoate treatment of agonadal men was reported to maintain sexual function for 9 weeks. ${ }^{36}$ Similarly, daily DHT gel administration for 6 months to men with andropause symptoms and serum $\mathrm{T}$ levels lower than 15 $\mathrm{nmol} / \mathrm{L}$ was more effective than placebo in restoring sexual function. $^{37}$

Much less is known about the role of estrogens in human male sexual behavior. ${ }^{38}$ In men with normal $\mathrm{T}$ levels, the administration of tamoxifen, an estrogen receptor antagonist, or testolactone, an aromatase inhibitor, did not modify sexual function. ${ }^{38}$ No remarkable sexual dysfunction was reported in men affected by congenital estrogen deficiency, suggesting that estrogens are not strictly necessary for normal male sexual behavior. $^{38}$ A double-blinded, placebo-controlled RCT evaluating the effect of the non-aromatization androgen DHT on 114 healthy men older than 50 years showed no effect on any of 33 measurements of sexual function and mood, apart from a mild, but significant, decrease in overall sexual desire, which was reversible after treatment cessation. ${ }^{39}$ However, an unexpected improvement in sexual desire and frequency of sexual activity occurred during transdermal E2 treatment in subjects affected by aromatase deficiency (a rare condition impairing estrogen formation), suggesting a possible role of estrogen in regulating male sexual desire. ${ }^{38}$ In addition, Finkelstein et $\mathrm{al}^{40}$ in a double-blinded, placebo-controlled experimental model of gonadotropin-releasing hormone analog-induced hypogonadism performed in 400 healthy men, showed that estrogen and $\mathrm{T}$ deficiencies contributed to the decrease of sexual function. In particular, the enrolled men were previously treated with goserelin acetate to suppress endogenous $\mathrm{T}$ and $\mathrm{E} 2$ production and then randomly assigned to receive a placebo, $\mathrm{T}$ alone, or $\mathrm{T}$ gel and anastrozole to suppress the conversion of $\mathrm{T}$ to $\mathrm{E} 2$. In the group that received $\mathrm{T}$ alone, inhibition of estrogen synthesis compared with intact estrogen synthesis was associated with significant increases in the percentage of body fat, subcutaneous fat area, intra-abdominal fat area, and significant decreases in sexual desire and EF, confirming that E2 exerts an independent effect on these variables. ${ }^{40}$

In contrast, data from the EMAS did not indicate any association between E2 and overall sexual function in middle-aged and older men. ${ }^{41}$ Similar results were reported in the CHAMP study and the TTrials. ${ }^{8,9}$ Hence, more data are advisable to clarify the specific role of estrogen in male sexual function and, in particular, in the control of sexual desire.

\section{RECOMMENDATION 2}

- DHT and estrogens play a minor role in the regulation of male sexual desire (level 2B).
- DHT and E2 evaluations are not recommended in men complaining of decreased sexual desire (level 3B).

\section{DHEA and Other Adrenal Hormones}

An age-dependent decrease of circulating DHEA and DHEAS has been reported, suggesting a role for these adrenal hormones in the age-dependent impairment of several biological functions, including the sexual ones. ${ }^{42,43}$ Granata et $\mathrm{al}^{44}$ evaluated sexual function in a small prospective study involving 12 subjects with autoimmune primary adrenal insufficiency who were studied before (baseline) and after 2 months of adrenal hormone supplementation. They found that DHEAS levels did not correlate with any of the sexual parameters studied, including sexual desire, at baseline or in the recovery phase. Granata et $\mathrm{al}^{44}$ also reported that subjects with adrenal insufficiency had lower scores in all domains, including sexual desire (as measured by the International Index of Erectile Function [IIEF]), which were normalized after replacement with cortisol and aldosterone. However, the improvement of the sexual desire domain was not confirmed after the adjustment for cortisol and renin levels during the recovery phase, suggesting an indirect, if any, role of the gluco- and mineralocorticoids in regulating male sexual desire. ${ }^{44}$

Several uncontrolled studies have indicated a positive effect of DHEA administration on sexual functions, including libido. ${ }^{51}$ Corona et $\mathrm{al}^{45}$ recently published a meta-analysis of placebocontrolled RCTs evaluating the effect of DHEA administration in elderly men. They found that DHEA did not significantly improve sexual desire in aging men. Similar results were reported in a recent double-blinded, placebo-controlled RCT enrolling 21 men with hypoactive sexual desire. ${ }^{46}$

The European Registry on Cushing's Syndrome documented that excess cortisol was associated with a $69 \%$ decrease of libido in affected men. ${ }^{47}$ However, it is unknown whether cortisol played a direct role in the regulation of male sexual desire or whether the latter relation was the result of the morbidities associated with excess cortisol, including hypogonadism and mood disturbances. ${ }^{47}$

\section{RECOMMENDATION 3}

- Adrenal hormones, including DHEA and DHEAS (level 2A), and cortisol and aldosterone (level 3B) are not involved in the regulation of male sexual desire.

- Adrenal hormone evaluation is not recommended in men complaining of decreased sexual desire (level 1A).

\section{Prolactin}

An epidemiologic study conducted in middle-aged and elderly European men did not demonstrate any association between variation in PRL levels and sexual desire. ${ }^{48}$ However, in this study, a low PRL level was associated with a negative change in sexual functioning compared with the previous year. ${ }^{48}$ In apparent 

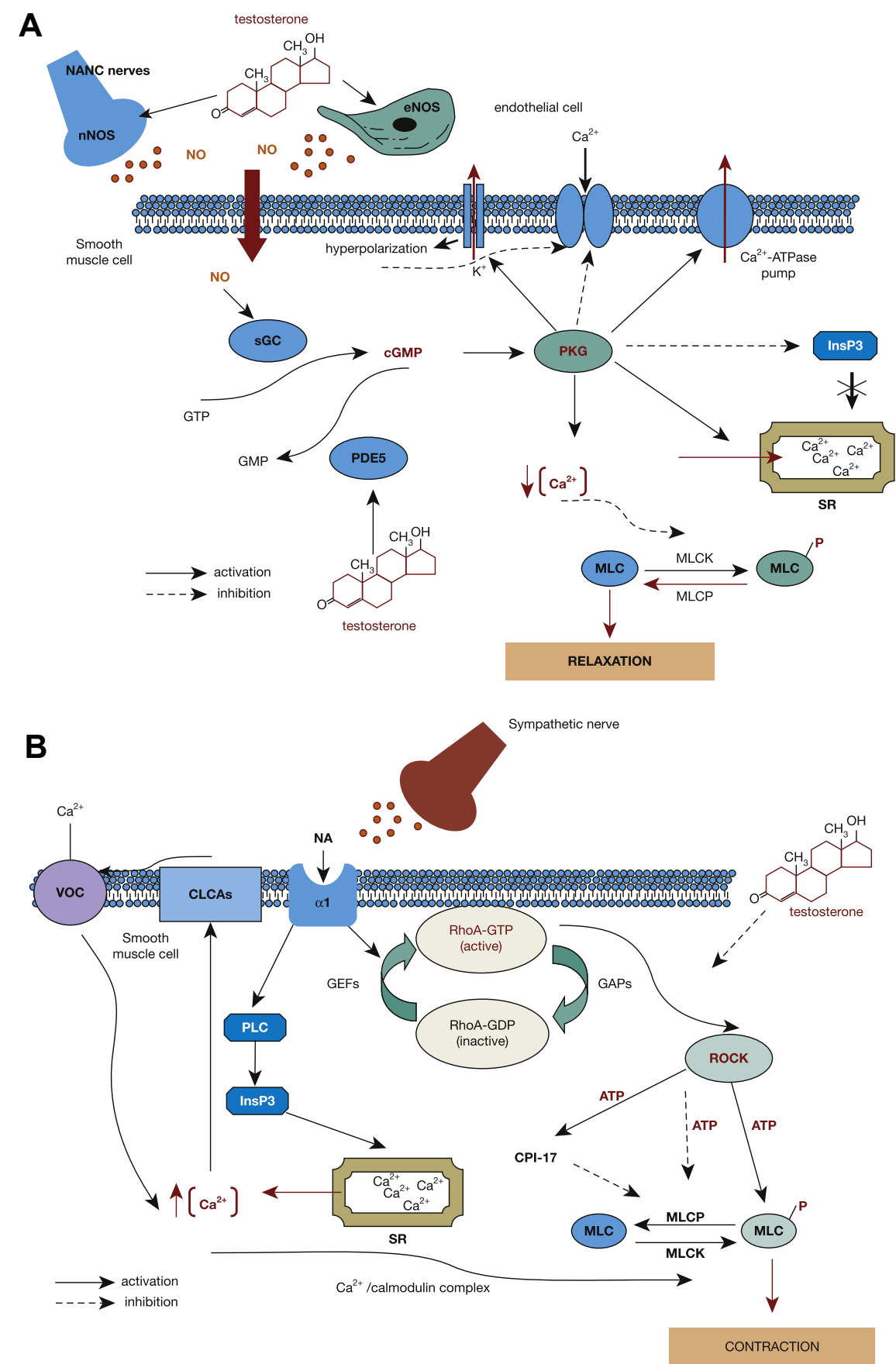

Figure 2. Role of testosterone in the mechanism of penile erection. Panel A depicts the generation of NO by NOS in NANC neurons (nNOS) or endothelial cells (eNOS). This step is positively regulated by testosterone. NO diffuses into smooth muscle cells and activates sCC, which in turn transforms GTP into cGMP. cGMPactivates PKG, which, through the indicated pathways, decreases intracellular $\mathrm{Ca}^{2+}$ levels, leading to relaxation. PDE5 metabolizes CGMP into GMP, thereby limiting its effects. The latter event is positively controlled by testosterone. Panel $B$ depicts the generation of InsP3 by NA binding to $\alpha_{1}$-receptors. InsP3, by increasing $\mathrm{Ca}^{2+}$ levels, activates CLCAs, resulting in membrane depolarization and the opening of VOC. Increased $\mathrm{Ca}^{2+}$ flow promotes, through calmodulin, activation of MLCK and cell contraction. Cell contraction also is obtained by a second pathway, RhoA/ROCK, which increases, through a series of kinase activations, the sensitivity of MLC to $\mathrm{Ca}^{2+}$. Testosterone is supposed to negatively regulate the latter event. Adapted from Corona and Maggi. ${ }^{61}$ ATPase $=$ adenosine triphosphatase; $\mathrm{Ca}^{2+}=$ intracellular calcium; CC = corpora cavernosa; $\mathrm{CGMP}=$ cyclic guanosine monophosphate; $\mathrm{CLCAs}=\mathrm{Ca}^{2+}$-sensitive chloride channels; eNOS $=$ endothelial nitric oxide synthase; GAPs = Rhol-GTP activating proteins; GEFs = guanine nucleotide-exchange factors; GTP = guanosine triphosphate; InsP3 = inositol 1,4,5-trisphosphate; MLC = myosin light chain; MLCK = myosin light chain kinase; MLCP = myosin light chain phosphate; $N A=$ noradrenaline; $N A N C=$ non-adrenergic and non-cholinergic; NNOS = neuronal nitric oxide synthase; NO = nitric oxide; NOS = nitric oxide synthase; $\mathrm{P}=$ phosphate; $\mathrm{PDES}=$ phosphodiesterase type 5; PKG = protein kinase $\mathrm{G}$; $\mathrm{sCC}$ = soluble guanylate cyclase; $\mathrm{SR}=$ sarcoplasmic reticulum; $\mathrm{VOC}=$ voltage-operated channels. Figure 2 is available in color online at www.jsm.jsexmed.org. 
contrast, in a cohort of men consulting for sexual dysfunction, a severely decreased libido was associated with a 10 times higher chance of having severe hyperprolactinemia (SHPRL; defined as PRL $>735 \mathrm{mU} / \mathrm{L}$ or $35 \mathrm{ng} / \mathrm{mL}$ ), whereas no association was observed between mild hyperprolactinemia (defined as PRL $>420$ $\mathrm{mU} / \mathrm{L}$ or $20 \mathrm{ng} / \mathrm{mL}$ and $<735 \mathrm{mU} / \mathrm{L}$ or $35 \mathrm{ng} / \mathrm{mL}$ ) and low desire. ${ }^{49}$ Similar data were reported in a more recent study aimed at identifying risk factors related to primary decreased libido (ie, not associated with known conditions causing low libido, such as hypogonadism, hyperprolactinemia, psychopathology, and/or psychoactive medications) or secondary decreased libido (ie, associated with these conditions), involving more than 3,700 men with sexual dysfunction. ${ }^{2}$ In subjects with SHPRL, decreased libido was almost universally present (84.2\%), whereas only fewer than $1 \%$ of patients consulting for sexual dysfunction had SHPRL. However, in this cohort, two of three subjects with SHPRL had a pituitary tumor or some other organic problem; therefore, such patients must be identified. ${ }^{2,49}$

The mechanisms by which PRL regulates male sexual desire are not completely understood (Figure 1). A PRL-induced hypogonadism could explain, at least in part, the association between SHPRL and decreased libido. ${ }^{42}$ In fact, PRL acutely increased the turnover of dopamine (DA) in several brain areas partly involved in the regulation of sexual behavior (ie, nigrostriatal and mesolimbic tracts) and of PRL secretion (ie, tuberoinfundibular tract). ${ }^{1}$ In particular, in the tuberoinfundibular tract, chronic hyperprolactinemia resulted in an increase in DA secretion leading to suppression of gonadotropin-releasing hormone, low luteinizing hormone, and low $\mathrm{T} .{ }^{1,42}$ Accordingly, SHPRL-induced central hypogonadism is a common finding. However, a direct effect of increased PRL on sexual desire also was hypothesized. ${ }^{1,42}$ In fact, PRL receptors were found in the diencephalic incertohypothalamic dopaminergic system, a pathway of short axons with terminals in the medial preoptic area, the most important area for the control of motivational and consummatory aspects of sexual behavior. ${ }^{1,42}$ In the incertohypothalamic dopaminergic system in contrast to other areas, PRL inhibited, or did not increase, DA activity, supporting a direct, negative effect of PRL on sexual motivation. ${ }^{1,42,50}$

A detailed list of causes of hyperprolactinemia has been reported elsewhere. ${ }^{42}$

DA agonists (bromocriptine and cabergoline) are the first choice in treating hyperprolactinemia, in particular PRLsecreting adenomas, because of their higher efficacy in normalizing PRL levels and a higher frequency of pituitary tumor shrinkage. ${ }^{42}$ In most cases, these PRL-lowering agents normalize hypoactive sexual desire, in addition to PRL and T levels. After treatment with dopaminergic drugs, hypoactive sexual desire normalizes in almost $70 \%$ to $90 \%$ of patients. ${ }^{42}$

As mentioned earlier, DA plays a crucial role acting as a neurotransmitter in regulating sexual excitation, particularly at the hypothalamic and mesolimbic levels. ${ }^{11}$ Accordingly, many patients are treated off label with DA agonists to help increase sexual desire. Despite this evidence, the specific role of DA in regulating male sexual desire is not completely clear. The best clinical example in this regard is represented by patients with Parkinson disease (PD). Sexual dysfunction and decreased libido, in particular, are common in patients with PD and it is closely associated with depression and relationship dissatisfaction. ${ }^{51}$ In addition, the use of DA agonist has been associated with an improvement of sexual desire and with impulse control disorders, a frequent complication of PD, with an estimated prevalence of 3\% to $4 \% .{ }^{51,52}$ Nevertheless, it is not clear whether the known brain "lesions" related to PD (supposedly relevant for maintaining normal sexual function) have a decisive impact on the prevalence of sexual dysfunction observed in PD. ${ }^{51}$ In fact, Lipe et al ${ }^{53}$ reported no difference in the prevalence of sexual dysfunction when PD was compared with another, non-neurologic, chronic disease such as arthritis, suggesting that factors other than DA impairment might play a more important role. In support of this notion, Kummer et $\mathrm{al}^{54}$ reported that age and depressive symptoms were the main predictors of loss of libido in patients with PD.

\section{RECOMMENDATION 4}

- PRL plays a major role in regulating male sexual desire (level 2A), acting through direct and indirect pathways (level 3B).

- PRL levels should be evaluated in all men complaining of decreased sexual desire (level 2A).

- Treating hyperprolactinemia restores sexual desire (level 2A).

\section{Thyroid Hormones}

Hypothyroidism in men is another endocrine condition previously associated with decreased libido. In a small prospective study, Carani et $\mathrm{al}^{55}$ evaluated the prevalence of sexual dysfunctions in 48 men, 34 with hyperthyroidism and 14 with hypothyroidism, and their possible remission after normalizing TH levels. They found that low sexual desire was related to hypothyroidism and that it was restored after TH therapy. The mechanism of action of $\mathrm{TH}$ on sexual desire is unknown. Although a hypothyroidism-induced increase in $\mathrm{PRL}^{42}$ might mediate the negative effects of low $\mathrm{TH}$ on sexual desire, a direct role of $\mathrm{TH}$ on the serotoninergic system has been postulated. ${ }^{55}$ More recently, Corona et $\mathrm{al}^{56}$ confirmed the association between low sexual desire and hypothyroidism in two different populations of subjects, including the aforementioned EMAS cohort and more than 3,000 patients consulting for sexual dysfunction. Hence, more studies are advisable to confirm the possible role of THs in the control of male sexual desire.

\section{RECOMMENDATION 5}

- The contribution of $\mathrm{THs}$ in the regulation of male sexual desire is contradictory (level 3B).

- TH evaluation is not recommended in men complaining of decreased sexual desire (level 2B) 


\section{HORMONES AND SEXUAL AROUSAL AND ERECTIONS}

\section{Sex Steroids (T, DHT, and E2)}

Role of T: Summary of Evidence From Experimental Studies

Androgens are considered the major hormonal regulator of penile development and physiology ${ }^{57}$ (Figure 1). In humans, $\mathrm{T}$ influences penile development, mainly because of extracellular stromal expansion. ${ }^{58}$ Postnatal penile length and growth rate also seem to be correlated with the $\mathrm{T}$ surge occurring in the first months of life (mini-puberty). ${ }^{59}$ However, no further correlation is seen in postpubertal adults. Most studies agree that androgen sensitivity and androgen receptor expression vary with age and stage of penile development. As a result, the role of $T$ in adult ED has been the object of several controversies. Most early studies focused on androgen ablation in animal models, a condition that can hardly be transferred to the human physiology of an erection, with the few exceptions of bilateral orchiectomy for testicular cancer and androgen deprivation for prostate cancer. However, some recent studies on hypogonadism induced by a high-fat diet recapitulated the findings from castration studies. ${ }^{59,60}$

Part of the erectile response to $\mathrm{T}$ is mediated through an increased sexual desire, but several experimental studies have documented a direct role of $\mathrm{T}$ on cavernous SMCs involving NO, PDE5, RhoA-ROCK, cavernosal nerve function, and adrenergic response (Figures 1 and 2). ${ }^{61}$

All experimental studies agree on a castration-induced decrease in intracavernous pressure caused by decreased arterial inflow and altered veno-occlusion during erection. Although the data from surgical hypogonadism hardly represent a very small minority of cases of human male hypogonadism, the animal model of hypogonadism induced by a high-fat diet seems to recapitulate the findings of castration studies. The NO pathway clearly represents a major target of androgens ${ }^{62,63}$ (Figure 2); however, studies of animals treated with L-N G-nitro arginine methyl ester also found additional NO-independent mechanisms that still required intact cGMP generation to control veno-occlusion. ${ }^{64}$ Among the NO-independent targets of androgens is the RhoAROCK pathway ${ }^{65}$ that keeps SMCs stably contracted by calcium sensitization; hypogonadism has been shown to induce activation of ROCK $1,{ }^{60}$ counteracting SMC relaxation, but not ROCK2, which, conversely, is increased by $\mathrm{T}$ in endothelial cells $^{66}$ (Figure 2). Another NO-independent mechanism is the regulation of smooth muscle myosin isoforms, ${ }^{67}$ and impaired renewal of subtunical cells also has been described in hypogonadism, contributing to impaired veno-occlusion. ${ }^{68}$ Several, but not all, ${ }^{69}$ studies found that PDE5 expression was regulated by androgens $s^{63,70,71}$ (Figure 2). In general, experimental studies converge in showing that androgens are necessary to sustain the NO-cGMP pathway through direct ${ }^{70,71}$ or indirect $^{72}$ mechanisms. ${ }^{73}$ A recent study reported that estrogens inhibit, more than androgens stimulate, PDE5 expression and activity. ${ }^{73}$
Another recognized mechanism of androgen action is the regulation of $\alpha_{1}$-adrenergic responsiveness of SMCs ${ }^{63,74}$ (Figure 2). Consistent findings have pointed toward an effect of $\mathrm{T}$ on postganglionic parasympathetic neurons or, even further upstream, within the autonomic nervous system. ${ }^{75}$ Therefore, androgens appear necessary to support adequate neuronal stimulation to the corpora cavernosa and maintain structural integrity in tissue as seen after the denervation from prostate surgery in men. ${ }^{68,75}$

\section{RECOMMENDATION 6}

- T regulates penile development and growth in early life, but not after puberty (level A).

- T targets several molecular pathways involved in the physiology of erections, including the NO-cGMP pathway (level A), RhoA-ROCK signaling, adrenergic response, and cavernous SMC turnover (level B).

\section{Role of T: Summary of Evidence From Clinical Studies}

Human studies are extremely heterogeneous in their assessment of EF; for the present synthesis, "overall EF" includes sexual-related and spontaneous erections, whereas "sexual-related EF" refers to the function exclusively assessed in the context of a sexual encounter (Sexual Encounter Profile, IIEF, and others). ${ }^{4}$

The EMAS and other cross-sectional surveys have reported lower T levels in approximately $30 \%$ of men with ED. ${ }^{6,7,39,76-79}$ Longitudinal studies have confirmed this association by showing that an individual's decrease (change $[\Delta]$ ) to the hypogonadal range, rather than its absolute value, predicts sexual decline. However, this relation is weaker for EF compared with desire and still does not imply any causal association., 9

Early studies found that the androgen dependency of EF in young men was maintained at threshold values that were far below those required to maintain the function of other target organs. ${ }^{80}$ However, this finding does not automatically translate to elderly men with comorbidities (ie, the vast majority of men complaining of ED). Of note is that aging is associated with an increase in SHBG that can lower bioavailable $\mathrm{T}$. This suggests that free $\mathrm{T}$ could be a better predictor of the association between EF and androgens. Although in principle this works, the direct measurement of free $\mathrm{T}$, or its calculation by SHBG, is disadvantaged by the reliability vs. costs of proper assays and uncertainties in SHBG polymorphism and its affinity to $T$. In the past, most studies were performed using total rather than free $\mathrm{T}$, and the $\mathrm{EMAS}^{7}$ did not show a superiority of one or the other. Nevertheless, more data collected with an accurate direct measurement of free $T$ in the future could indicate a stronger prediction of $E F$.

The few available RCTs addressing the role of T on ED have been extensively reviewed, with the largest and most updated meta-analysis confirming significant beneficial effects on overall EF, but only in men with a T level lower than $12 \mathrm{nmol} / \mathrm{L} .{ }^{4}$ Regression and subgroup analyses have emphasized a role for aging as a possible moderator of $\mathrm{ED}$ responsiveness to $\mathrm{T}$. Specifically, data on sexual-related EF 
Table 2. Characteristics and Outcomes of Phase 1 and 2 Studies Evaluating Effects of Oxytocin or $\alpha$-MSH Analogs on Several Sexual Function Parameters

\begin{tabular}{|c|c|c|c|c|c|c|c|c|c|}
\hline Study & & $\begin{array}{l}\text { Sample } \\
\text { size }\end{array}$ & $\begin{array}{l}\text { Population } \\
\text { studied }\end{array}$ & Age $(y)$ & Drug & $\begin{array}{l}\text { Duration of } \\
\text { treatment }\end{array}$ & Type of study & Erectile response & Side effects \\
\hline \multicolumn{10}{|l|}{ Oxytocin } \\
\hline $\begin{array}{l}\text { Behnia et } \mathrm{al}_{,}{ }^{98} \\
2014\end{array}$ & - & 29 & $\begin{array}{l}\text { Healthy } \\
\text { heterosexual } \\
\text { couples }\end{array}$ & - & $\begin{array}{l}\text { Intranasal oxytocin } \\
\text { application (24 IU) }\end{array}$ & Acute & Single arm & $\begin{array}{l}\text { Psychometric } \\
\text { questionnaires, } \\
\uparrow \text { orgasm, } \\
\uparrow \text { sexual satiety }\end{array}$ & - \\
\hline $\begin{array}{l}\text { Burri et al, } \\
1998\end{array}$ & - & 10 & Healthy men & - & $\begin{array}{l}\text { Intranasal oxytocin } \\
\text { application (24 IU) }\end{array}$ & Acute & $\begin{array}{l}\text { Double-blinded, } \\
\text { placebo- } \\
\text { controlled, } \\
\text { balanced } \\
\text { crossover }\end{array}$ & $\begin{array}{l}\text { ASES, equivocal } \\
\text { effects on sexual } \\
\text { behavior }\end{array}$ & - \\
\hline $\begin{array}{l}\text { Scheele } \\
\text { et al, } \\
2013\end{array}$ & - & 20 & $\begin{array}{l}\text { Healthy non- } \\
\text { smoking } \\
\text { male } \\
\text { volunteers }\end{array}$ & 25.5 & $\begin{array}{l}\text { Intranasal oxytocin } \\
\text { application (24 IU) }\end{array}$ & Acute & $\begin{array}{l}\text { Double-blinded, } \\
\text { discovery and } \\
\text { replication study }\end{array}$ & $\begin{array}{l}\text { MRI, female } \\
\text { partner's face } \\
\text { more attractive } \\
\text { vs unfamiliar } \\
\text { women, } \\
\text { augmented } \\
\text { neural response } \\
\text { to partner vs. } \\
\text { familiar woman }\end{array}$ & - \\
\hline
\end{tabular}

MSH analog

\begin{tabular}{|c|c|c|c|c|c|c|c|}
\hline $\begin{array}{c}\text { Royalty et al, } \\
1012014\end{array}$ & $\begin{array}{l}\text { Single-dose trial } \\
\text { design (part } \\
\text { 1) }\end{array}$ & 6 & $\begin{array}{l}\text { Healthy } \\
\text { overweight } \\
\text { and obese } \\
\text { subjects }\end{array}$ & 35.2 & $\begin{array}{l}\text { Long-acting } \alpha-\mathrm{MSH} \quad 22 \mathrm{~d} \\
\text { analog }(0.03 \mathrm{mg} / \\
\text { kg) MC4-NN2- } \\
0453\end{array}$ & 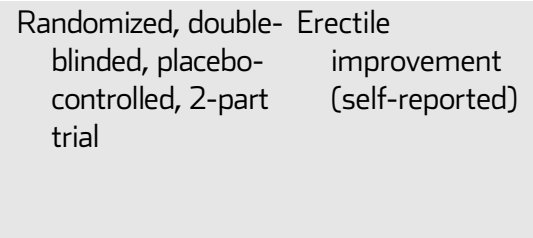 & $\begin{array}{l}\text { Skin hyperpigmentation } \\
(33 \%), \text { headache } \\
(30 \%) \text {, decreased } \\
\text { appetite (12\%), } \\
\text { injection-site } \\
\text { hemorrhage }\end{array}$ \\
\hline & & 6 & & 32.3 & $\begin{array}{l}\text { Long-acting } \alpha \text {-MSH } \\
\text { analog MC4-NN2- } \\
0453(0.06 \mathrm{mg} / \mathrm{kg})\end{array}$ & & \\
\hline & & 6 & & 39.3 & $\begin{array}{l}\text { Long-acting } \alpha-\mathrm{MSH} \\
\text { analog MC4-NN2- } \\
0453(0.15 \mathrm{mg} / \mathrm{kg})\end{array}$ & & \\
\hline & & 6 & & 35.2 & $\begin{array}{l}\text { Long-acting } \alpha \text {-MSH } \\
\text { analog MC4-NN2- } \\
0453(0.30 \mathrm{mg} / \mathrm{kg})\end{array}$ & & \\
\hline & & 7 & & 37.6 & $\begin{array}{l}\text { Long-acting } \alpha \text {-MSH } \\
\text { analog MC4-NN2- } \\
0453(0.60 \mathrm{mg} / \mathrm{kg})\end{array}$ & & \\
\hline
\end{tabular}




\begin{tabular}{|c|c|c|c|c|c|c|c|c|c|}
\hline \multirow[t]{6}{*}{ Study } & & $\begin{array}{l}\text { Sample } \\
\text { size }\end{array}$ & $\begin{array}{l}\text { Population } \\
\text { studied }\end{array}$ & Age (y) & Drug & $\begin{array}{l}\text { Duration of } \\
\text { treatment }\end{array}$ & Type of study & Erectile response & Side effects \\
\hline & & 6 & & 35.0 & $\begin{array}{l}\text { Long-acting } \alpha \text {-MSH } \\
\text { analog MC4-NN2- } \\
0453(1.00 \mathrm{mg} / \mathrm{kg})\end{array}$ & & & & \\
\hline & & 6 & & 31.8 & $\begin{array}{l}\text { Long-acting } \alpha-\mathrm{MSH} \\
\quad \text { analog }(1.50 \mathrm{mg} / \mathrm{kg})\end{array}$ & & & & \\
\hline & $\begin{array}{l}\text { Multiple-Dose } \\
\text { Trial Design } \\
\text { (Part 2) }\end{array}$ & 25 & $\begin{array}{l}\text { Healthy obese } \\
\text { subjects }\end{array}$ & 43.8 & $\begin{array}{l}\text { Long-acting } \alpha \text {-MSH } \\
\text { analog MC4-NN2- } \\
0453(0.75 \mathrm{mg} / \mathrm{d})\end{array}$ & $210 \mathrm{~d}$ & & & \\
\hline & & 50 & & 38.6 & $\begin{array}{l}\text { long-acting } \alpha \text {-MSH } \\
\text { analog MC4-NN2- } \\
0453(1.50 \mathrm{mg} / \mathrm{d})\end{array}$ & & & & \\
\hline & & 25 & & 41.4 & $\begin{array}{l}\text { long-acting } \alpha \text {-MSH } \\
\text { analog MC4-NN2- } \\
0453 \text { (3.00 mg/d) }\end{array}$ & & & & \\
\hline \multirow[t]{2}{*}{$\begin{array}{l}\text { Rosen et al, } \\
2004\end{array}$} & $\begin{array}{l}\text { Phase 1 study } \\
\text { (SC 0.3, 1, 3, } \\
5,7.5,10 \mathrm{mg} \text { ) }\end{array}$ & 36 & Healthy men & 33.6 & $\begin{array}{l}\text { Melanocortin receptor } \\
\text { agonist PT-141 }\end{array}$ & Acute & $\begin{array}{l}\text { Randomized, } \\
\text { double-blinded, } \\
\text { placebo- } \\
\text { controlled, 2- } \\
\text { phase trial }\end{array}$ & $\begin{array}{l}\text { RigiScan, } \uparrow \text { duration } \\
\text { of rigidity }>60 \% \\
\text { (min), } \uparrow \text { duration } \\
\text { of rigidity }>80 \% \\
\text { (min; for dosage } \\
\leq 1 \mathrm{mg} \text { ) }\end{array}$ & $\begin{array}{l}\text { Nausea, headache, } \\
\text { flushing (average } \\
30 \% \text { of population } \\
\text { for higher dosages) }\end{array}$ \\
\hline & $\begin{array}{l}\text { Phase } 2 \text { study } \\
\text { (SC 4-6 mg) }\end{array}$ & 25 & $\begin{array}{l}\text { Patients with } \\
\text { ED not } \\
\text { responsive to } \\
\text { sildenafil }\end{array}$ & 48 & $\begin{array}{l}\text { Melanocortin receptor } \\
\text { agonist PT-141 }\end{array}$ & & & $\begin{array}{l}\text { RigiScan, } \uparrow \text { duration } \\
\text { of rigidity }>60 \% \\
\text { (min), } \uparrow \text { duration } \\
\text { of rigidity }>80 \% \\
\text { (min) }\end{array}$ & \\
\hline \multirow[t]{2}{*}{$\begin{array}{l}\text { Diamond } \\
\text { et } \mathrm{al}_{1}^{103} \\
2004\end{array}$} & $\begin{array}{l}\text { Phase } 1 \text { study, } \\
\text { nasal spray } \\
(4,7,10,20 \\
\text { mg) }\end{array}$ & 24 & $\begin{array}{l}\text { Healthy } \\
\text { subjects }\end{array}$ & 33.5 & $\begin{array}{l}\text { Melanocortin receptor } \\
\text { agonist PT-141 }\end{array}$ & Acute & $\begin{array}{l}\text { Randomized, } \\
\text { double-blinded, } \\
\text { placebo- } \\
\text { controlled, 2- } \\
\text { phase trial }\end{array}$ & $\begin{array}{l}\text { RigiScan, } \uparrow \text { duration } \\
\text { of rigidity }>60 \% \\
\text { (min), } \uparrow \text { duration } \\
\text { of rigidity }>80 \% \\
\text { (min) }\end{array}$ & Nausea, flushing \\
\hline & $\begin{array}{l}\text { Phase } 2 \text { study, } \\
\text { nasal spray } \\
(7-20 \mathrm{mg})\end{array}$ & 24 & $\begin{array}{l}\text { Patients with } \\
\text { ED } \\
\text { responsive to } \\
\text { sildenafil }\end{array}$ & 50.9 & & & & $\begin{array}{l}\text { RigiScan, } \uparrow \text { duration } \\
\text { of rigidity }>60 \% \\
\text { (min), } \uparrow \text { duration } \\
\text { of rigidity }>80 \% \\
\text { (min) }\end{array}$ & \\
\hline
\end{tabular}

(continued) 


\begin{tabular}{|c|c|c|c|c|c|c|c|c|c|}
\hline Study & & $\begin{array}{l}\text { Sample } \\
\text { size }\end{array}$ & $\begin{array}{l}\text { Population } \\
\text { studied }\end{array}$ & Age (y) & Drug & $\begin{array}{l}\text { Duration of } \\
\text { treatment }\end{array}$ & Type of study & Erectile response & Side effects \\
\hline \multirow[t]{2}{*}{$\begin{array}{l}\text { Wessells } \\
\text { et al, } 104 \\
2000\end{array}$} & - & 10 & Psychogenic ED & 47.4 & $\begin{array}{c}\text { Melanotan II } 0.025 \pm \\
0.157 \mathrm{mg} / \mathrm{kg}\end{array}$ & Acute & $\begin{array}{l}\text { Double blinded, } \\
\text { placebo- } \\
\text { controlled } \\
\text { crossover }\end{array}$ & $\begin{array}{l}\text { RigiScan, } \uparrow \text { duration } \\
\text { of rigidity }>80 \% \\
\text { (min), } \uparrow \text { sexual } \\
\text { desire }\end{array}$ & $\begin{array}{l}12 \text { with severe nausea } \\
\text { (12.9\% of subjects) }\end{array}$ \\
\hline & & 10 & Organic ED & 56.2 & & & & & $\begin{array}{l}\text { Nausea with stretching } \\
\text { or yawning }\end{array}$ \\
\hline $\begin{array}{l}\text { Wessells } \\
\quad \text { et al, }{ }_{105}^{105} 1998\end{array}$ & - & 10 & Psychogenic ED & 47 & $\begin{array}{l}\text { Melanotan II (0.025 } \\
\mathrm{mg} / \mathrm{kg})\end{array}$ & Acute & $\begin{array}{l}\text { Double-blinded, } \\
\text { placebo- } \\
\text { controlled } \\
\text { crossover study }\end{array}$ & $\begin{array}{l}\text { RigiScan, } \uparrow \text { duration } \\
\quad \text { of rigidity }>80 \% \\
\quad \text { (min) }\end{array}$ & $\begin{array}{l}\text { Transient nausea with } \\
\text { stretching and } \\
\text { yawning }\end{array}$ \\
\hline $\begin{array}{l}\text { Safarinejad } \\
\text { et al, } \\
2008\end{array}$ & - & 342 & $\begin{array}{l}\text { Patients with } \\
\text { ED not } \\
\text { responsive to } \\
\text { sildenafil }\end{array}$ & $28-59$ & $\begin{array}{l}\text { Intranasal } \\
\text { bremelanotide } 10 \\
\text { mg }\end{array}$ & & $\begin{array}{l}\text { Double-blinded, } \\
\text { placebo- } \\
\text { controlled study }\end{array}$ & $\begin{array}{l}\text { IIEF score, } \uparrow \text { sexual } \\
\text { satisfaction } \\
\text { domain }\end{array}$ & - \\
\hline $\begin{array}{l}\text { Krishna } \\
\text { et } \mathrm{al}_{1}^{107} \\
2008\end{array}$ & $\begin{array}{l}\text { Treatments } \\
\quad \text { (placebo; } \\
\text { 200-mg } \\
\text { single oral } \\
\text { dose of MK- } \\
\text { 0493; 500- } \\
\text { mg single oral } \\
\text { dose of MK- } \\
\text { 0493; 50-mg } \\
\text { single oral } \\
\text { dose of } \\
\text { sildenafil) }\end{array}$ & 20 & Organic ED & $35-50$ & $\begin{array}{l}\text { Melanocortin } 4 \\
\text { receptor agonist } \\
\text { (MK-0493) }\end{array}$ & Acute & $\begin{array}{l}\text { Randomized, double- } \\
\text { blinded, placebo- } \\
\text { controlled, 4- } \\
\text { period crossover } \\
\text { study }\end{array}$ & $\begin{array}{l}\text { RigiScan, } \uparrow \text { duration } \\
\text { of rigidity }>60 \% \\
\quad \text { (min) }\end{array}$ & Nausea, vomiting \\
\hline
\end{tabular}

ASES = Acute Sexual Experience Scale; ED = erectile dysfunction; IIEF = International Index of Erectile Function; MRI = magnetic resonance imaging; MSH = melanocyte-stimulating hormone; $\mathrm{SC}=$ subcutaneous. 
were available in 19 studies enrolling 1,431 individuals $^{12-18,21-26,30,81,125-130}$ (Table 1). Overall, TTh determined an improvement only in studies enrolling hypogonadal subjects (mean baseline $\mathrm{T}$ levels $<12 \mathrm{nmol} / \mathrm{L}$ ), but not in those investigating eugonadal patients or mixed eugonadal and hypogonadal subjects. A sensitivity analysis performed in the few trials $(n=6)$ using IIEF-EF domain score as an outcome measurement confirmed the positive effect of TTh on the sexual-related EF component (IIEF-15 EF subdomain $\Delta$ increase of $3.726,95 \%$ $\mathrm{CI}=1.621-5.830, P<.001)$.

More recently, the concept of "compensated" or "subclinical hypogonadism" has been introduced, suggesting that when $T$ decreases from a previously higher level, the increase in luteinizing hormone might become a confirmatory biomarker for insufficient androgenization. ${ }^{82-84}$ Another relevant emerging aspect is the time course of $\mathrm{T}$ effects (ie, length of treatment necessary to achieve the maximum result). Recent systematic reviews ${ }^{85}$ and $\mathrm{RCTs}^{25,80,81}$ have found that although the effects on libido, ejaculation, and sexual activity occur within just 2 to 3 weeks, effects on EF could require up to 6 or even 12 months.

\section{RECOMMENDATION 7}

- The decrease of circulating $\mathrm{T}$ level is associated with a decrease in EF (level 2B).

- TTh in hypogonadal men (total T level $<12 \mathrm{nmol} / \mathrm{L}$ ) is associated with significant increases in self-reported measurements of EF that are proportional to the severity of hypogonadal status before treatment (level 1A).

- Basal and longitudinal assessments of $\mathrm{T}$ are recommended in men with ED (level 1A).

\section{Role of DHT}

DHT is the most potent androgen involved in genital tissue development. No major discrepancies could be found when comparing the in vitro effects of $\mathrm{T}$ and DHT on EF. However, interest in the role of DHT has been renewed recently by patients complaining of sexual-related symptoms after exposure to 5ARis. ${ }^{86}$ Studies have pointed toward a drug-related, rather than DHT-mediated, effect. In animal models, 5ARis have been associated with structural and functional alterations in penile tissue contributing to penile fibrosis that is mainly exerted through a modulation of cholinergic and adrenergic sensitivity, with no apparent change in PDE5. ${ }^{87}$ However, the available evidence is insufficient to determine whether defective DHT, in the presence of normal $\mathrm{T}$, impairs EF in men. The few trials performed on hypogonadal subjects treated with DHT alone or $\mathrm{T}$ plus 5ARi found similar effects on major EF domains. ${ }^{37,88}$

\section{RECOMMENDATION 8}

- DHT exerts qualitatively similar effects as T on EF (level 2A), but it has been less extensively studied.
- Treatment using DHT and its analogs (mesterolone) cannot be recommended as an alternative to TTh to improve EF in hypogonadal men (level 4B).

- Measurement of DHT is not recommended in the assessment of EF (level 3A).

\section{Role of Estrogens}

E2 was found to be required to maintain male sexual function in some, but not all, studies of selective estrogen deficiency. ${ }^{36,41}$ The EMAS showed that E2 correlated with psychological symptoms of male aging, ${ }^{41}$ but not with EF domains, confirming previous findings. ${ }^{5,89}$ These studies found a robust, independent correlation between E2 and sexual dysfunction-associated distress and $\mathrm{T}$ associated with somatized anxiety in older men with ED. ${ }^{90}$ A recent RCT found that aromatization played only a minor role in the maintenance of sexual function in healthy men, with some dependence on increasing age and obesity. ${ }^{39}$ More recently, a longitudinal study found an association between estrone and the onset of ED during a 2-year follow-up.? Measurement of estrogens in men is not reliable with immunoassays; therefore, their use as biomarkers is possible only if adequate detection systems are available.

\section{RECOMMENDATION 9}

- The role of E2 on EF is controversial. Experimental evidence indicates that E2 downregulates PDE5 expression (level 3C).

- Measurement of estrogens is not recommended in the assessment of EF (level 2C).

\section{DHEA and Other Adrenal Hormones}

Past evidence documented a possible role of an agedependent decrease of DHEAS in the pathogenesis of ED. ${ }^{42,43}$ The MMAS found that DHEAS was the only hormone negatively correlated to the prevalence of ED among 17 investigated hormones, including $\mathrm{T}$ and E2. ${ }^{91}$ In addition, Basar et al, ${ }^{92}$ in a consecutive series of 348 men, reported that DHEAS and free $\mathrm{T}$ levels were significantly lower in men with sexual dysfunction as determined by the IIEF score. However, more recent data have advocated against an association between DHEA (and its DHEAS) and ED. A large placebo-controlled RCT evaluating the effect of DHEA in elderly men and women with an observational period up to 2 years failed to demonstrate a physiologically relevant beneficial effect on ED. ${ }^{93}$ Similarly, Morales et al ${ }^{94}$ reported that DHEA treatment (50 mg twice daily) did not induce significant differences in sexual performance outcomes compared with placebo as assessed by the IIEF, the Androgen Deficiency in the Aging Male questionnaire, the Aging Male Symptom Scale, and the Global Assessment Questionnaire. Similarly a meta-analysis evaluating the effect of DHEA administration in elderly men 
indicated that DHEA supplementation did not improve the overall score of the IIEF-15 or EF domain total score. ${ }^{45}$

The prevalence of ED in patients with Cushing syndrome is unknown. In particular, no information has been reported in the European Registry on Cushing's Syndrome. ${ }^{47}$ Granata et al ${ }^{44}$ found that in subjects with adrenal insufficiency, treatment with glucocorticoids and mineralocorticoids independently improved the EF domain of the IIFF.

\section{RECOMMENDATION 10}

- DHEA and DHEAS are not involved in the regulation of male EF (level 2A).

- Glucocorticoid and mineralocorticoid in adrenal insufficiency might play a role in restoring EF (level 4C).

\section{Prolactin}

The relation between hyperprolactinemia and EF is under debate. Some researchers have suggested a possible pathogenic link between severe ED and SHPRL. ${ }^{42}$ However, Corona et $\mathrm{al}^{49}$ did not confirm a significant association between SHPRL and severe ED after adjustment for confounders, including $\mathrm{T}$ levels. Hence, SHPRL-induced hypogonadism could explain, at least in part, the association between ED and SHPRL. In apparent contrast with these findings, the same group reported that in subjects with sexual dysfunction, low PRL ( $<10 \mathrm{ng} / \mathrm{mL}$ or $210 \mathrm{mU} / \mathrm{L}$ ) was associated with arteriogenic ED. ${ }^{95}$ This finding was confirmed in the European general population by the EMAS. ${ }^{48}$ Some experimental studies have indicated that acute, but not chronic, pharmacologic elevation of brain PRL is associated with a facilitated, rather than an impaired, sexual behavior, including increased penile erection, mounting, and intromission activity. ${ }^{42}$ Similarly, in a populationbased birth cohort study of men from the Philippines, basal PRL was inversely related to mating effort as indicated by the number of the men's lifetime sexual partners and the sexual activity in the month preceding the PRL measurement. ${ }^{96}$ In that study, men without offspring who reported no sexual activity and/or the smallest number of sexual partners had the lowest concentrations of PRL. ${ }^{96}$ All these findings indicate that PRL might have a more positive, than negative, effect on initiating or maintaining sexual behavior. It is still unclear how PRL might facilitate male sexual behavior. Different mechanisms could be advocated to explain these associations. In fact, low PRL in the peripheral circulation could mirror, within the hypothalamus, an increase of dopaminergic or a decrease of serotoninergic signaling. The latter possibility represents the most intriguing hypothesis.

\section{ו}

- PRL does not play a direct role in the regulation of male EF (level 3B).

- PRL evaluation is not recommended in patients complaining of ED (level 2B).
- Treating hyperprolactinemia might have indirect, positive effects on arousal and erection (level 3B).

\section{Oxytocin}

OT is a nonapeptide synthesized in the supraoptic and paraventricular nuclei of the hypothalamus and released by the posterior pituitary. In contrast to its clear function in female reproduction (regulation of milk ejection reflex and uterine contractility), the physiologic role in men is unclear. Animal models have indicated that OT plays a key role in the central control of penile erection, at the level of the paraventricular nuclei of the hypothalamus and of the spinal cord. ${ }^{97}$ In particular, OT increases the activity of mesolimbic and mesocortical dopaminergic neurons originating in the ventral tegmental area and projecting to the nucleus accumbens and to the medial prefrontal cortex. ${ }^{97}$ Accordingly, mesolimbic and mesocortical dopaminergic neurons play a key role in the motivational and rewarding properties of natural reinforcing stimuli, including sexual activity. ${ }^{97}$ The mechanism by which OT induces penile erection and activates mesolimbic dopaminergic neurons when injected into the ventral subiculum or into the posteromedial nucleus of the amygdala is only partly understood. In these areas, OT also activates its own receptors that lead to the activation of NO synthase, thereby increasing $\mathrm{NO}$ production. $\mathrm{NO}$ in turn activates unknown efferent projections, which apparently increase glutamatergic neurotransmission in the ventral tegmental area. ${ }^{97}$ In particular, DA released from these neurons is believed to mediate the transposition of the motivational aspects of natural stimuli into goal-directed behaviors, as in sexual activity, seeking a sexual partner, and sexual intercourse to achieve reward and satisfaction. ${ }^{97}$ Altogether, these neural pathways might constitute a complex hypothetical circuit, which plays a role not only in the consummatory phase of sexual activity (EF and copulation) but also in the motivational and rewarding aspects of the anticipatory phase of sexual behavior.

Despite this strong experimental evidence, knowledge about the effects of OT on human sexual behaviors and partner interactions is scanty (Table 2)..$^{98-107}$ In an uncontrolled observational study involving 29 healthy heterosexual couples, Behnia et $\mathrm{al}^{98}$ analyzed the acute effects of intranasally administered OT (24 IU) on drive, arousal, orgasm, and refractory aspects of sexual behavior, together with partner interactions. They reported that men indicated higher levels of sexual satiety after sexual intercourse and women felt more relaxed and subgroups indicated an increased ability to share sexual desires or to empathize with their partners. However, the effect was small to moderate. In a previous small RCT with the same dose of OT administered intranasally, a lack of effect of active treatment was found on several sexual parameters, including arousal. ${ }^{99}$ In a double-blinded, placebo-controlled RCT, a specific effect of intranasal OT was found in perceiving the partner as attractive, with magnetic resonance imaging-derived activation of brain regions involved in reward, such as the ventral tegmental area and the nucleus accumbens, but without a specific effect on arousal. ${ }^{100}$ 
Hence, there is a growing idea that OT in humans is important in pair bonding and in enhancing attractiveness during romantic love, as found in other mammals. ${ }^{100}$

\section{RECOMMENDATION 12}

- Conclusive data regarding the potential therapeutic role of OT in male sexual dysfunctions are lacking (level 2B).

\section{Growth Hormone}

GH is a 191-amino acid polypeptide synthesized and secreted under the control of GH-releasing hormone (positive) and somatostatin (negative) of somatotroph cells in the anterior pituitary. Its primary role is to promote linear bone growth. The physiologic role of $\mathrm{GH}$ on sexual function has not been fully elucidated. Experimental studies have shown that GH can induce dose-dependent relaxation of human corpus cavernosal strips in vitro and an increase in cGMP, ${ }^{108,109}$ but the GH concentration needed to elicit a $30 \%$ relaxation was at least three orders of magnitude higher than the GH concentration changes recorded in cavernosal blood sampling during the physiologic process of erection in men. ${ }^{110}$ Pastuszak et $\mathrm{al}^{111}$ reported that IGF-1 levels correlated with sexual function score in 65 men scheduled for radical prostatectomy. In contrast to these findings, Miwa et $\mathrm{al}^{112}$ did not find any correlation between peripheral $\mathrm{GH}$ levels and all aspects of the Aging Male Symptom Scale including sexual function in ambulatory men. In a small series of patients, cavernous GH levels in organic and psychogenic ED did not differ from peripheral levels. ${ }^{113}$

Although ED and decreased libido are often reported as symptoms of acromegaly in textbooks, ${ }^{114}$ it is still unclear whether this is due to the excess of GH or a consequence of GH-related morbidities including secondary hypogonadism. Recently, Lotti et $\mathrm{al}^{115}$ published the first study that systematically analyzed EF in 57 subjects with acromegaly. Although $42.1 \%$ of patients analyzed complained of ED, it was not related to several acromegaly-related parameters, including IGF-1 levels, type of treatment, duration of disease, or secondary hypogonadism. Conversely, subjects with ED and acromegaly had higher cardiovascular risk factors and worse impairment of penile vascular flow compared with subjects with acromegaly and without ED. ${ }^{115}$ These data indicate that ED in acromegaly is not related to abnormalities of GH or IGF-1 or T levels but is associated with cardiac morbidities related to the disease. Hence, exposure to excess GH probably does not directly affect $\mathrm{EF}$ in vivo and caution is needed when results obtained by in vitro studies are transposed in vivo to humans. In line with these findings, GH replacement treatment did not modify sexual function in men with GH deficiency. ${ }^{116}$

\section{RECOMMENDATION 13}

- $\mathrm{GH}$ and IGF-1 are not involved in the regulation of male EF (level 3B).
- GH and IGF-1 levels should not be evaluated in men complaining of ED (level 2B).

\section{Melanocortin}

Melanocortins are a family of peptide hormones, including adrenocorticotrophic hormone and $\alpha-, \beta$-, and $\gamma$-MSHs, derived from the cleavage of a large precursor peptide, namely proopiomelanocortin. Experimental animal models indicated that the interaction of $\alpha$ - and $\beta$-MSH with specific melanocortin receptors (MCR3 and MCR4) within the hypothalamus and limbic system led to a typical behavioral syndrome including grooming, stretching, and yawning, spontaneous penile erection and ejaculation, and increased sexual receptivity. ${ }^{117}$ Two synthetic analogs of $\alpha$-MSH have been developed for human use (melanotan; afamelanotide, formerly CUV1647; and bremelanotide, formerly PT-141). Phase 1 and 2 trials have been completed and are presented in Table $2^{101-107}$ (for review, see Ückert et al ${ }^{117}$ ). However, in all studies, drug-related adverse effects were present, such as nausea, yawning, and flushing, which limited the attractiveness of this treatment. In addition, there were concerns regarding a possible increase in blood pressure. ${ }^{117}$

\section{RECOMMENDATION 14}

- Animal models indicate that the melanocortin system is involved in the regulation of EF acting at a central level (level 2C).

- Available RCTs do no suggest analogs of $\alpha$-MSH for the treatment of ED because of associated adverse events (level 1B).

\section{Thyroid Hormones}

Although thyroid dysfunctions are often highlighted as common ED-associated conditions, ${ }^{42}$ only a few evidence-based reports have investigated this aspect. In 2005, in a small Italian study, Carani et $\mathrm{al}^{55}$ documented that hypo- and hyperthyroidism were commonly associated with ED (as detected by validated questionnaires). Similar results were confirmed in two other small studies from Italy ${ }^{118}$ and Greece. ${ }^{119}$ Interestingly, Carani et $\mathrm{al}^{55}$ and Krassas et $\mathrm{al}^{119}$ further documented that the correction of the underlying thyroid disorders restored EF. More recently, Corona et $\mathrm{al}^{56}$ evaluated the relation between $\mathrm{TH}$ and EF in a large series $(\mathrm{N}=3,203)$ of patients seeking medical care for sexual dysfunction and in the EMAS population. They found that hyperthyroidism, but not hypothyroidism, was associated with an increased risk of severe $\mathrm{ED}$, after adjusting for confounding factors, including $\mathrm{T}$ and PRL levels. These associations were confirmed in nested case-control analyses comparing subjects with overt hyperthyroidism with controls matched for age, body mass index, smoking status, and $\mathrm{T}$ levels. ${ }^{56}$ Similarly, in a retrospective analysis of a health insurance database representative of Taiwan's general population, Keller et $\mathrm{al}^{120}$ reported that subjects with ED were 1.64 times more likely to have been previously diagnosed with hyperthyroidism compared with control individuals without ED. TH- $\alpha$ and $\mathrm{TH}-\beta$ receptors were described in rat and human corpora cavernosa endothelial cells 
and SMCs. ${ }^{121,122}$ Studies in animal models of hyperthyroidism indicated an impairment of NO-dependent relaxation of corpora cavernosa. ${ }^{123}$ In rabbit corpora cavernosa strips, relaxation induced by acetylcholine and electrical field stimulation was impaired, whereas sensitivity to the $\mathrm{NO}$ donor, sodium nitroprusside, was unchanged. ${ }^{123}$ These data suggest an effect of $\mathrm{TH}$ in penile NO formation, which has been demonstrated in a rat model. ${ }^{125}$ Therefore, hyperthyroidism-associated ED could be due to a direct effect of TH on penile cognate receptors (for review, see Krassas et $\mathrm{al}^{123}$ ). Despite this evidence, Maseroli et $\mathrm{al}^{124}$ reported that the prevalence of thyroid disorders in patients seeking medical care for $\mathrm{ED}$ was rather low $(<1 \%)$ and not different from that observed in the general population of the same geographic area.

\section{RECOMMENDATION 15}

- Hyperthyroidism is significantly associated with an increased risk of ED (level 3B).

- Treating hyperthyroidism improves ED (level 3B).

- Sexual function should be assessed in all men with hyperthyroidism (level 3B).

- The prevalence of hyperthyroidism in men seeking medical care for ED is low (level 2B).

- $\mathrm{TH}$ evaluation is not recommended in all men complaining of ED (level 2B).

- The association between hypothyroidism and impairment of EF is contradictory (level 2C).

- Sexual function should not be assessed in all men with hypothyroidism (level 2B).

- The prevalence of hypothyroidism in men seeking medical care for ED is low (level 2B).

- TH evaluation is not recommended in all men complaining of ED (level 2B).

\section{CONCLUSIONS}

Several hormones modulate or even promote human sexual behavior, including libido and arousal. Although epidemiologic and intervention studies corroborate the crucial role of $\mathrm{T}$ in inducing and maintaining sexual desire and erection, results for other hormones are less clear. Hypothalamic neurohormones as OT and $\alpha$-MSH are currently under active research for therapeutic purposes. However, results from pilot studies are disappointing for lack of consistency or for disappointing side effects. Aside from hypogonadism, other endocrine disorders are associated with sexual dysfunctions. However, apart from hyperprolactinemia, their investigation in men seeking medical care for sexual dysfunction is not recommended because of the current lack of convincing evidence.

Corresponding Author: Prof. Mario Maggi, Sexual Medicine and Andrology Unit, Department of Biomedical, Clinical and Experimental Sciences, University of Florence, Florence, Italy.
Viale Pieraccini 6, 50139 Florence, Italy. Tel.: +39-554271415. Fax: +39-55-4271413; E-mail: m.maggi@dfc.unifi.it

Conflict of Interest: The authors report no conflicts of interest. Funding: None.

\section{REFERENCES}

1. Bancroft J. The endocrinology of sexual arousal. J Endocrinol 2005; 186:411.

2. Corona G, Rastrelli G, Ricca $V$, et al. Risk factors associated with primary and secondary reduced libido in male patients with sexual dysfunction. J Sex Med 2013; 10:1074.

3. Corona G, Rastrelli G, Maseroli E, et al. Sexual function of the ageing male. Best Pract Res Clin Endocrinol Metab 2013; 27:581.

4. Corona G, Isidori AM, Buvat J, et al. Testosterone supplementation and sexual function: a meta-analysis study. J Sex Med 2014; 11:1577.

5. Gades NM, Jacobson DJ, McGree ME, et al. The associations between serum sex hormones, erectile function, and sex drive: the Olmsted County Study of Urinary Symptoms and Health Status among Men. J Sex Med 2008; 5:2209.

6. Travison TG, Morley JE, Araujo AB, et al. The relationship between libido and testosterone levels in aging men. J Clin Endocrinol Metab 2006; 91:2509.

7. Wu FC, Tajar A, Beynon JM, et al, EMAS Group. Identification of late-onset hypogonadism in middle-aged and elderly men. N Engl J Med 2010; 363:123.

8. Cunningham GR, Stephens-Shields AJ, Rosen RC, et al. Association of sex hormones with sexual function, vitality, and physical function of symptomatic older men with low testosterone levels at baseline in the testosterone trials. J Clin Endocrinol Metab 2015; 100:1146.

9. Hsu B, Cumming RG, Blyth FM, et al. The longitudinal relationship of sexual function and androgen status in older men: the Concord Health and Ageing in Men Project. J Clin Endocrinol Metab http://dx.doi.org/jc20144104. E-pub ahead of print.

10. Rastrelli G, Carter EL, Ahern T, et al. Development of and recovery from secondary hypogonadism in ageing men: prospective results from the EMAS. J Clin Endocrinol Metab http://dx.doi.org/jc20151571. E-pub ahead of print.

11. Pfaus JG. Pathways of sexual desire. J Sex Med 2009; 6:1506.

12. O'Carroll R, Bancroft J. Testosterone therapy for low sexual interest and erectile dysfunction in men: a controlled study. $\mathrm{Br}$ J Psychiatry 1984; 145:146.

13. Anderson RA, Bancroft J, Wu FC. The effects of exogenous testosterone on sexuality and mood of normal men. J Clin Endocrinol Metab 1999; 75:1503.

14. Svartberg J, Aasebø U, Hjalmarsen A, et al. Testosterone treatment improves body composition and sexual function in men with COPD, in a 6-month randomized controlled trial. Respir Med 2004; 98:906.

15. Gluud C, Wantzin P, Eriksen J. No effect of oral testosterone treatment on sexual dysfunction in alcoholic cirrhotic men. Gastroenterology 1988; 95:1582. 
16. Schiavi RC, White D, Mandeli J, et al. Effect of testosterone administration on sexual behavior and mood in men with erectile dysfunction. Arch Sex Behav 1997; 26:231.

17. Rabkin JG, Wagner GJ, Rabkin R. A double-blind, placebocontrolled trial of testosterone therapy for HIV-positive men with hypogonadal symptoms. Arch Gen Psychiatry 2000; 57:141.

18. Haren M, Chapman I, Coates P, et al. Effect of 12 month oral testosterone on testosterone deficiency symptoms in symptomatic elderly males with low-normal gonadal status. Age Ageing 2005; 34:125.

19. Nankin HR, Lin T, Osterman J. Chronic testosterone cypionate therapy in men with secondary impotence. Fertil Steril 1986; 46:300.

20. Dobs AS, Hoover DR, Chen MC, et al. Pharmacokinetic characteristics, efficacy, and safety of buccal testosterone in hypogonadal males: a pilot study. J Clin Endocrinol Metab 1998; 83:33.

21. Steidle C, Schwartz S, Jacoby K, et al, North American AA2500 T Gel Study Group. AA2500 testosterone gel normalizes androgen levels in aging males with improvements in body composition and sexual function. J Clin Endocrinol Metab 2003; 88:2673.

22. Seftel $A D$, Mack RJ, Secrest AR, et al. Restorative increases in serum testosterone levels are significantly correlated to improvements in sexual functioning. J Androl 2004; 25:963.

23. Cavallini G, Caracciolo S, Vitali G, et al. Carnitine versus androgen administration in the treatment of sexual dysfunction, depressed mood, and fatigue associated with male aging. Urology 2004; 63:641.

24. Jones TH, Arver S, Behre HM, et al, TIMES2 Investigators. Testosterone replacement in hypogonadal men with type 2 diabetes and/or metabolic syndrome (the TIMES2 study). Diabetes Care 2011; 34:828.

25. Hackett G, Cole N, Bhartia M, et al. Testosterone replacement therapy with long-acting testosterone undecanoate improves sexual function and quality-of-life parameters vs. placebo in a population of men with type 2 diabetes. J Sex Med 2013; 10:1612.

26. Skakkebaek NE, Bancroft J, Davidson DW, et al. Androgen replacement with oral testosterone undecanoate in hypogonadal men: a double blind controlled study. Clin Endocrinol (Oxf) 1981; 14:49.

27. Bancroft J, Wu FC. Changes in erectile responsiveness during androgen replacement therapy. Arch Sex Behav 1983; 12:59.

28. Carani C, Zini D, Baldini A, et al. Effects of androgen treatment in impotent men with normal and low levels of free testosterone. Arch Sex Behav 1990; 19:223.

29. Clopper RR, Voorhess ML, MacGillivray MH, et al. Psychosexual behavior in hypopituitary men: a controlled comparison of gonadotropin and testosterone replacement. Psychoneuroendocrinology 1993; 18:149.

30. Chiang HS, Cho SL, Lin YC, et al. Testosterone gel monotherapy improves sexual function of hypogonadal men mainly through restoring erection: evaluation by IIEF score. Urology 2009; 73:762.
31. Buvat J, Maggi M, Guay A, et al. Testosterone deficiency in men: systematic review and standard operating procedures for diagnosis and treatment. J Sex Med 2013; 10:245.

32. Corona G, Baldi E, Maggi M. Androgen regulation of prostate cancer: where are we now? J Endocrinol Invest 2011; 34:232.

33. Corona G, Gacci M, Baldi E, et al. Androgen deprivation therapy in prostate cancer: focusing on sexual side effects. J Sex Med 2012; 9:887.

34. Brinkmann L, Schuetzmann K, Richter-Appelt H. Gender assignment and medical history of individuals with different forms of intersexuality: evaluation of medical records and the patients' perspective. J Sex Med 2007; 4:964.

35. Gur S, Kadowitz PJ, Hellstrom WJ. Effects of 5-alpha reductase inhibitors on erectile function, sexual desire and ejaculation. Expert Opin Drug Saf 2013; 12:81.

36. Gooren LJG. Human male sexual functions do not require aromatization of testosterone: a study using tamoxifen, testolactone, and dihydrotestosterone. Arch Sex Behav 1985; $14: 539$.

37. Kunelius $\mathrm{P}$, Lukkarinen $\mathrm{O}$, Hannuksela ML, et al. The effects of transdermal dihydrotestosterone in the aging male: a prospective, randomized, double blind study. J Clin Endocrinol Metab 2002; 87:1467.

38. Rochira V, Carani C. Aromatase deficiency in men: a clinical perspective. Nat Rev Endocrinol 2009; 5:559.

39. Sartorius GA, Ly LP, Handelsman DJ. Male sexual function can be maintained without aromatization: randomized placebo-controlled trial of dihydrotestosterone (DHT) in healthy, older men for 24 months. J Sex Med 2014; $11: 2562$.

40. Finkelstein JS, Yu EW, Burnett-Bowie SA. Gonadal steroids and body composition, strength, and sexual function in men. N Engl J Med 2013; 369:2457.

41. O'Connor DB, Lee DM, Corona G, et al. European Male Ageing Study Group. The relationships between sex hormones and sexual function in middle-aged and older European men. J Clin Endocrinol Metab 2011; 96:E1577-E1587.

42. Maggi M, Buvat J, Corona G, et al. Hormonal causes of male sexual dysfunctions and their management (hyperprolactinemia, thyroid disorders, GH disorders, and DHEA). J Sex Med 2013; 10:661.

43. Traish AM, Kang HP, Saad F, et al. Dehydroepiandrosterone (DHEA) - a precursor steroid or an active hormone in human physiology. J Sex Med 2011; 8:2960.

44. Granata A, Tirabassi G, Pugni V, et al. Sexual dysfunctions in men affected by autoimmune Addison's disease before and after short-term gluco- and mineralocorticoid replacement therapy. J Sex Med 2013; 10:2036.

45. Corona G, Rastrelli G, Giagulli VA, et al. Dehydroepiandrosterone supplementation in elderly men: a meta-analysis study of placebo-controlled trials. J Clin Endocrinol Metab 2013; 98:3615.

46. Bloch M, Meiboom H, Zaig I, et al. The use of dehydroepiandrosterone in the treatment of hypoactive sexual desire disorder: a report of gender differences. Eur Neuropsychopharmacol 2013; 23:910. 
47. Valassi E, Santos A, Yaneva M, et al, ERCUSYN Study Group. The European Registry on Cushing's syndrome: 2-year experience. Baseline demographic and clinical characteristics. Eur J Endocrinol 2011; 165:383.

48. Corona G, Wu FC, Rastrelli G, et al, EMAS Study Group. Low prolactin is associated with sexual dysfunction and psychological or metabolic disturbances in middle-aged and elderly men: the European Male Aging Study (EMAS). J Sex Med 2014; 11:240.

49. Corona G, Mannucci E, Fisher AD, et al. Effect of hyperprolactinemia in male patients consulting for sexual dysfunction. J Sex Med 2007; 4:1485.

50. Lookingland KJ, Moore KE. Effects of estradiol and prolactin on incertohypothalamic dopaminergic neurons in the male rat. Brain Res 1984; 323:83.

51. Bronner G, Vodušek DB. Management of sexual dysfunction in Parkinson's disease. Ther Adv Neurol Disord 2011; 4:375.

52. Politis M, Loane C, Wu K, et al. Neural response to visual sexual cues in dopamine treatment-linked hypersexuality in Parkinson's disease. Brain 2013; 136:400.

53. Lipe $H$, Longstreth WT Jr, Bird TD, et al. Sexual function in married men with Parkinson's disease compared to married men with arthritis. Neurology 1990; 40:1347.

54. Kummer A, Cardoso F, Teixeira AL. Loss of libido in Parkinson's disease. J Sex Med 2009; 6:1024.

55. Carani C, Isidori AM, Granata A, et al. Multicenter study on the prevalence of sexual symptoms in male hypo- and hyperthyroid patients. J Clin Endocrinol Metab 2005; 90:6472.

56. Corona G, Wu FC, Forti G, et al, EMAS Study Group. Thyroid hormones and male sexual function. Int J Androl 2012; 35:668.

57. Boas M, Boisen KA, Virtanen HE, et al. Postnatal penile length and growth rate correlate to serum testosterone levels: a longitudinal study of 1962 normal boys. Eur J Endocrinol 2006; 154:125.

58. Baskin LS, Sutherland RS, DiSandro MJ, et al. The effect of testosterone on androgen receptors and human penile growth. J Urol 1997; 158:1113.

59. Filippi S, Vignozzi L, Morelli A, et al. Testosterone partially ameliorates metabolic profile and erectile responsiveness to PDE5 inhibitors in an animal model of male metabolic syndrome. J Sex Med 2009; 6:3274.

60. Vignozzi L, Morelli A, Filippi S, et al. Testosterone regulates RhoA/Rho-kinase signaling in two distinct animal models of chemical diabetes. J Sex Med 2007; 4:620.

61. Corona G, Maggi M. The role of testosterone in erectile dysfunction. Nat Rev Urol 2010; 7:46.

62. Lugg J, Ng C, Rajfer J, et al. Cavernosal nerve stimulation in the rat reverses castration-induced decrease in penile NOS activity. Am J Physiol Endocrinol Metab 1996; 271:E354.

63. Traish AM, Park K, Dhir V, et al. Effects of castration and androgen replacement on erectile function in a rabbit model. Endocrinology 1999; 140:1861.

64. Reilly CM, Lewis RW, Stopper VS, et al. Androgenic maintenance of the rat erectile response via a non-nitric-oxide-dependent pathway. J Androl 1997; 18:588.
65. Sopko NA, Hannan JL, Bivalacqua TJ. Understanding and targeting the Rho kinase pathway in erectile dysfunction. Nat Rev Urol 2014; 11:622.

66. Liao W, Huang W, Guo $Y$, et al. Testosterone promotes vascular endothelial cell migration via upregulation of ROCK2/moesin cascade. Mol Biol Rep 2013; 40:6729.

67. Zhang XH, Melman A, Disanto ME. Update on corpus cavernosum smooth muscle contractile pathways in erectile function: a role for testosterone? J Sex Med 2011; 8:1865.

68. Traish AM, Toselli P, Jeong SJ, et al. Adipocyte accumulation in penile corpus cavernosum of the orchiectomized rabbit: a potential mechanism for veno-occlusive dysfunction in androgen deficiency. J Androl 2005; 26:242.

69. Yang R, Huang YC, Lin G, et al. Lack of direct androgen regulation of PDE5 expression. Biochem Biophys Res Commun 2009; 380:758.

70. Morelli A, Filippi S, Mancina R, et al. Androgens regulate phosphodiesterase type 5 expression and functional activity in corpora cavernosa. Endocrinology 2004; 145:2253.

71. Zhang XH, Morelli A, Luconi M, et al. Testosterone regulates PDE5 expression and in vivo responsiveness to tadalafil in rat corpus cavernosum. Eur Urol 2005; 47:409.

72. Andric SA, Janjic MM, Stojkov NJ, et al. Testosterone-induced modulation of nitric oxide-cGMP signaling pathway and androgenesis in the rat Leydig cells. Biol Reprod 2010; 83:434.

73. Vignozzi L, Filippi S, Comeglio P, et al. Estrogen mediates metabolic syndrome-induced erectile dysfunction: a study in the rabbit. J Sex Med 2014; 11:2890.

74. Reilly CM, Stopper VS, Mills TM. Androgens modulate the alpha-adrenergic responsiveness of vascular smooth muscle in the corpus cavernosum. J Androl 1997; 18:26.

75. Isidori AM, Buvat J, Corona G, et al. A critical analysis of the role of testosterone in erectile function: from pathophysiology to treatment-a systematic review. Eur Urol 2014; 65:99.

76. Kohler TS, Kim J, Feia K, et al. Prevalence of androgen deficiency in men with erectile dysfunction. Urology 2008; 71:693.

77. Tsertsvadze A, Fink HA, Yazdi $F$, et al. Oral phosphodiesterase-5 inhibitors and hormonal treatments for erectile dysfunction: a systematic review and meta-analysis. Ann Intern Med 2009; 151:650.

78. Travison TG, Morley JE, Araujo AB, et al. The relationship between libido and testosterone levels in aging men. J Clin Endocrinol Metab 2006; 91:2509.

79. Kupelian V, Shabsigh R, Travison TG, et al. Is there a relationship between sex hormones and erectile dysfunction? Results from the Massachusetts Male Aging Study. J Urol 2006; 176:2584.

80. Isidori AM, Balercia G, Calogero AE, et al. Outcomes of androgen replacement therapy in adult male hypogonadism: recommendations from the Italian society of endocrinology. J Endocrinol Invest 2015; 38:103.

81. Giltay EJ, Tishova YA, Mskhalaya GJ, et al. Effects of testosterone supplementation on depressive symptoms and 
sexual dysfunction in hypogonadal men with the metabolic syndrome. J Sex Med 2010; 7:2572.

82. Giannetta E, Gianfrilli D, Barbagallo F, et al. Subclinical male hypogonadism. Best Pract Res Clin Endocrinol Metab 2012; 26:539.

83. Tajar A, Forti G, O'Neill TW, et al. Characteristics of secondary, primary, and compensated hypogonadism in aging men: evidence from the European Male Ageing Study. J Clin Endocrinol Metab 2010; 95:1810.

84. Corona G, Maseroli E, Rastrelli G, et al. Characteristics of compensated hypogonadism in patients with sexual dysfunction. J Sex Med 2014; 11:1823.

85. Saad F, Aversa A, Isidori AM, et al. Onset of effects of testosterone treatment and time span until maximum effects are achieved. Eur J Endocrinol 2011; 165:675.

86. Traish AM, Hassani J, Guay AT, et al. Adverse side effects of 5alpha-reductase inhibitors therapy: persistent diminished libido and erectile dysfunction and depression in a subset of patients. J Sex Med 2011; 8:872.

87. Pinsky MR, Gur S, Tracey AJ, et al. The effects of chronic 5alpha-reductase inhibitor (dutasteride) treatment on rat erectile function. J Sex Med 2011; 8:3066.

88. Bhasin S, Travison TG, Storer TW, et al. Effect of testosterone supplementation with and without a dual 5alpha-reductase inhibitor on fat-free mass in men with suppressed testosterone production: a randomized controlled trial. JAMA 2012; 307:931.

89. Gades NM, Jacobson DJ, McGree ME, et al. The associations between serum sex hormones, erectile function, and sex drive: the Olmsted County Study of Urinary Symptoms and Health Status among Men. J Sex Med 2008; 5:2209.

90. Corona G, Mannucci E, Ricca V, et al. The age-related decline of testosterone is associated with different specific symptoms and signs in patients with sexual dysfunction. Int J Androl 2009; 32:720.

91. Feldman HA, Goldstein I, Hatzichristou DG, et al. Impotence and its medical and psychosocial correlates: results of the Massachusetts Male Aging Study. J Urol 1994; 151:54.

92. Basar MM, Aydin G, Mert HC, et al. Relationship between serum sex steroids and Aging Male Symptoms score and International Index of Erectile Function. Urology 2005; 66:597.

93. Nair KS, Rizza RA, O'Brien P, et al. DHEA in elderly women and DHEA or testosterone in elderly men. $\mathrm{N}$ Engl J Med 2006; 355:1647.

94. Morales A, Black A, Emerson L, et al. Androgens and sexual function: a placebo-controlled, randomized, double-blind study of testosterone vs. dehydroepiandrosterone in men with sexual dysfunction and androgen deficiency. Aging Male 2009; 12:104.

95. Corona G, Mannucci E, Jannini EA, et al. Hypoprolactinemia: a new clinical syndrome in patients with sexual dysfunction. J Sex Med 2009; 6:1457.

96. Gettler LT, McDade TW, Feranil AB, et al. Prolactin, fatherhood, and reproductive behavior in human males. Am J Phys Anthropol 2012; 148:362.
97. Argiolas A, Melis MR. Neuropeptides and central control of sexual behaviour from the past to the present: a review. Prog Neurobiol 2013; 108:80.

98. Behnia B, Heinrichs M, Bergmann W, et al. Differential effects of intranasal oxytocin on sexual experiences and partner interactions in couples. Horm Behav 2014; 65:308.

99. Burri A, Heinrichs M, Schedlowski M, et al. The acute effects of intranasal oxytocin administration on endocrine and sexual function in males. Psychoneuroendocrinology 2008; 33:591.

100. Scheele D, Wille A, Kendrick KM, et al. Oxytocin enhances brain reward system responses in men viewing the face of their female partner. Proc Natl Acad Sci U S A 2013; 110:20308.

101. Royalty JE, Konradsen G, Eskerod O, et al. Investigation of safety, tolerability, pharmacokinetics, and pharmacodynamics of single and multiple doses of a long-acting $\alpha$-MSH analog in healthy overweight and obese subjects. J Clin Pharmacol 2014; 54:394.

102. Rosen RC, Diamond LE, Earle DC, et al. Evaluation of the safety, pharmacokinetics and pharmacodynamic effects of subcutaneously administered PT-141, a melanocortin receptor agonist, in healthy male subjects and in patients with an inadequate response to Viagra. Int J Impot Res 2004; 16:135.

103. Diamond LE, Earle DC, Rosen RC, et al. Double-blind, placebocontrolled evaluation of the safety, pharmacokinetic properties and pharmacodynamic effects of intranasal PT-141, a melanocortin receptor agonist, in healthy males and patients with mildto-moderate erectile dysfunction. Int J Impot Res 2004; 16:51.

104. Wessells H, Gralnek D, Dorr R, et al. Effect of an alphamelanocyte stimulating hormone analog on penile erection and sexual desire in men with organic erectile dysfunction. Urology 2000; 56:641.

105. Wessells H, Fuciarelli K, Hansen J, et al. Synthetic melanotropic peptide initiates erections in men with psychogenic erectile dysfunction: double-blind, placebo controlled crossover study. J Urol 1998; 160:389.

106. Safarinejad MR, Hosseini SY. Salvage of sildenafil failures with bremelanotide: a randomized, double-blind, placebo controlled study. J Urol 2008; 179:1066.

107. Krishna R, Wong P, Stevens C, et al. Lack of erectogenic activity of a novel selective melanocortin-4 receptor agonist in a clinical experimental model. J Clin Pharmacol 2008; 48:1237.

108. Becker AJ, Uckert S, Stief CG, et al. Possible role of human growth hormone in penile erection. J Urol 2000; $164: 2138$

109. Uckert S, Scheller F, Stief CG, et al. Potential mechanism of action of human growth hormone on isolated human penile erectile tissue. Urology 2010; 75:968.

110. Becker AJ, Uckert S, Stief CG, et al. Serum levels of human growth hormone during different penile conditions in the cavernous and systemic blood of healthy men and patients with erectile dysfunction. Urology 2002; 59:609.

111. Pastuszak AW, Liu JS, Vij A, et al. IGF-1 levels are significantly correlated with patient-reported measures of sexual function. Int J Impot Res 2011; 23:220. 
112. Miwa Y, Kaneda T, Yokoyama O. Correlation between the Aging Males' Symptoms Scale and sex steroids, gonadotropins, dehydroepiandrosterone sulfate, and growth hormone levels in ambulatory men. J Sex Med 2006; 3:723.

113. Hamed EA, Meki MA, Gaafar AAA, et al. Role of some vasoactive mediators in patients with erectile dysfunction: their relationship with angiotensin-converting enzyme and growth hormone. Int J Impot Res 2003; 15:418.

114. Melmed S, Kleinberg D. Anterior pituitary. In: Larsen PR, Kronenberg HM, Melmed S, et al., eds. Williams textbook of endocrinology. 17th ed. Philadelphia: Saunders; 2008:155.

115. Lotti F, Rochira V, Pivonello R, et al. Erectile dysfunction is common among men with acromegaly and is associated with morbidities related to the disease. J Sex Med 2015; 12:1184.

116. Brill KT, Weltman AL, Gentili A, et al. Single and combined effects of growth hormone and testosterone administration on measures of body composition, physical performance, mood, sexual function, bone turnover, and muscle gene expression in healthy older men. J Clin Endocrinol Metab 2002; 87:5649.

117. Ückert S, Bannowsky A, Albrecht K, et al. Melanocortin receptor agonists in the treatment of male and female sexual dysfunctions: results from basic research and clinical studies. Expert Opin Investig Drugs 2014; 23:1477.

118. Veronelli A, Masu A, Ranieri R, et al. Prevalence of erectile dysfunction in thyroid disorders: comparison with control subjects and with obese and diabetic patients. Int J Impot Res 2006; 18:111.

119. Krassas GE, Tziomalos K, Papadopoulou F, et al. Erectile dysfunction in patients with hyper- and hypothyroidism: how common and should we treat? J Clin Endocrinol Metab 2008; 93:1815.

120. Keller J, Chen YK, Lin HC. Hyperthyroidism and erectile dysfunction: a population-based case-control study. Int J Impot Res 2012; 24:242.
121. Owen PJ, Sabit R, Lazarus JH. Thyroid disease and vascular function. Thyroid 2007; 17:519.

122. Carosa E, Di Sante S, Rossi S, et al. Ontogenetic profile of the expression of thyroid hormone receptors in rat and human corpora cavernosa of the penis. J Sex Med 2010; 7:1381.

123. Krassas GE, Poppe K, Glinoer D. Thyroid function and human reproductive health. Endocr Rev 2010; 31:702.

124. Maseroli E, Corona G, Rastrelli G, et al. Prevalence of endocrine and metabolic disorders in subjects with erectile dysfunction: a comparative study. J Sex Med 2015; 12:956.

125. Aydin S, Odabas O, Ercan M, et al. Efficacy of testosterone, razodone and hypnotic suggestion in the treatment of nonorganic male sexual dysfunction. Br J Urol 1996; 77:256.

126. Benkert O, Witt W, Adam W, et al. Effects of testosterone undecanoate on sexual potency and the hypothalamic-pituitarygonadal axis of impotent males. Arch Sex Behav 1979; 8:471.

127. Seidman SN, Spatz E, Rizzo C, et al. Testosterone replacement therapy for hypogonadal men with major depressive disorder: a randomized, placebo-controlled clinical trial. J Clin Psych 2001; 62:406.

128. Chiang HS, Hwang TI, Hsui YS, et al. Transdermal testosterone gel increases serum testosterone levels in hypogonadal men in Taiwan with improvements in sexual function. Int J Impot Res 2007; 19:411.

129. Francomano D, llacqua A, Bruzziches R, et al. Effects of 5year treatment with testosterone undecanoate on lower urinary tract symptoms in obese men with hypogonadism and metabolic syndrome. Urology 2014; 83:167.

130. Aversa A, Bruzziches R, Francomano D, et al. Efficacy and safety of two different testosterone undecanoate formulations in hypogonadal men with metabolic syndrome. J Endocrinol Invest 2010; 33:776. 